\title{
Economic performance, social progress and institutional reform in European neighbouring countries
}

\begin{abstract}
The objective of this article is to analyse the recent evolution of European Neighbouring countries (ENC) in different dimensions related to economic performance (measured in a broader sense), social progress and institutional reforms. With this aim, we design and build a composite indicator to measure these different dimensions. Next, the index is used to characterise the relative evolution of neighbouring countries compared to a wide sample of developed and developing economies. We also test whether a convergence process has taken place in these different dimensions controlling for the potential effect of the European Neighbourhood Policy. The obtained results show different trends according to the considered dimensions and heterogeneous effects at the country level. From a policy perspective, these results reinforce the validity of the bilateral action plans that have characterized ENP recognising the different starting point and particular characteristics of each neighbouring country.
\end{abstract}

Keywords: Convergence, Social indicators, Economic performance, Institutional quality, European neighbourhood policy.

JEL Classification: C43, F62, O43 


\section{INTRODUCTION AND OBJECTIVES}

According to recent prospective studies (see for instance PWC, 2015) global economic power will continue shifting away from the established advanced economies in North America, the European Union and Japan over the next decades. As Fatas and Mihov (2009) highlight, for the first time in recent history the "periphery" is producing more good and services than the "core" and the consolidation of new actors in the global economy has occurred faster than ever. Didier et al (2012) have also shown that, although emerging economies have also suffered growth collapses, they have been more resilient and have continued growing and recovering pre-crisis levels faster than developed economies. In Europe, the economic situation resulting from the 2008 crisis cannot be explained by a simple North-South divide (Crescenzi et al., 2016) and the evolution in recent year has been quite diverse not only among European Union (EU) members but also in the European Neighbouring Countries (ENC) (European Commission, 2009). Several neighbouring countries in the East and South borders of the European Union were among the best economic performers in relative terms during the pre-crisis period. For instance, Lithuania, Latvia and Estonia were very often described as “Baltic Tigers” with GDP annual growth rates above 10\% from 2003 to 2007 (Dudzińska, 2013). The increase in oil prices from 2000 to 2008 together with the impact of the 2000's reforms lead Russia to record growth rates and an impressive improvement in the living standards of the population (World Economic Forum, 2013). In a similar way, countries in the Mediterranean area considered to be “lion economies” include several ENC as Algeria, Morocco, Egypt or Tunisia. Europe’s demographic and economic decline together with policies supporting a better integration in world markets have been key factors to explain the better performance of countries in the Mediterranean area during the last decades (World Economic Forum, 2011).

The objective of this paper is to analyse the recent evolution of the ENC not only by looking at GDP growth but considering different dimensions related to economic performance (measured in a broader sense), social progress and institutional reforms. The ENC performance in these different dimensions is compared to the one experienced by a wide sample of economies including not only developed economies but also developing and emerging ones. In order to facilitate this comparison, we develop a composite indicator capturing economic, institutional and social aspects of the different countries. Composite indicators are relevant tools for monitoring and policy assesment. As highlighted by Murillo et al. (2015), they provide a synthetic view about the evolution of variables of interest, but as the indicator breaks into simple indicators, they can also help policy makers to understand the strong and weak points of their economies and, if required, to simulate the results of different economic policies. Taking this into account, our proposal adds to the growing literature that tries to overcome the shortcomings of unidimensional approaches such as those focusing on Gross Domestic Product per capita or those based on multidimensional index such as the United Nations' Human Development Index that has been widely criticized in the literature (see, for instance, Wu et al, 2014). The wider perspective in the construction of the index will allow us to focus on different aspects using a homogeneous approach. In fact, the use of composite indicators to compare different dimensions between developed and emerging economies (and even within them) is not straightforward. The literature is currently expanding this view not only in economic terms but also on 
social and institutional dimension (see, for instance, Çolak and Ege, 2013; Mitra, 2013; Giambona and Vasallo, 2014 or Steendijk, 2015 as representative examples of this recent literature).

In this paper, we build a new multi-dimensional index in order to analyse the economic, social and institutional performance of ENC compared to a wide sample of developed and developing economies. Although several similar indexes exist nowadays, their composition and their time and country coverage are quite different to the one proposed here taking into account the objective of our analysis. For instance, the World Economic Forum Global Competitiveness Index (GCI) provides data for 140 economies (including ENC) but the first year for which data is available using the current methodology is 2005 while some of the actions related to ENP started in the end of the nineties ${ }^{1}$. Regarding the dimensions considered, and although the information is much more disaggregated, the main three pillars are basic requirements, efficiency enhancers and innovation and sophistication factors, aspects that cannot be easily associated to economic, institutional and social aspects. Other indexes such as the GEDI index ${ }^{2}$, or the Legatum Prosperity Index ${ }^{3}$ have similar limitations in terms of the time period covered. Last, the IMD World Competitiveness Yearbook ${ }^{4}$ covers a longer time period than most available indicators, but its main problem from the point of view of our analysis is its limited country coverage (61 economies), particularly regarding ENC.

An important aspect that we have to take into account when carrying out our comparative analysis of the ENC relative performance is the adoption of the European Neighbourhood Policy (ENP). The aim of this policy is to promote political and institutional changes towards democratic governance and market liberalisation, a process that at the same time is understood as a tool for economic development in neighbouring countries and convergence towards the European Union member states. ENP does not offer accession perspective to the EU for these countries, but promotes close political cooperation, close economic integration and access to the EU market as an incentive to carry out economic and institutional reforms with the aim also of improving the social cohesion in these countries. In fact, as highlighted by Dodini and Fantini (2006), the economic effects of the ENP would be related to three interrelated channels (structural reforms, macro policy anchor and trade and factor movement) that could allow neighbouring countries to benefit in the long run from positive impacts that would reduce their current gap with EU member states. Taking this into account, our analysis has to consider the potential effects of this policy on the relative evolution of ENC.

Considering this background, in the second section of the paper we summarise the scarce literature that has analysed up to now the impact of ENP on the relative performance of the affected countries. Next, in the third section, we describe the methodology used to elaborate the Institutional, Social and Economic Performance Index (ISEPI). In the fourth section, we analyse the regional differences in the evolution of this index (and its components) through the comparison of ENC with a wider sample of economies. Last,

\footnotetext{
${ }^{1}$ http://reports.weforum.org/global-competitiveness-report-2015-2016/competitiveness-rankings/

2 http://thegedi.org/research/gedi-index/

3 http://www.prosperity.com

${ }^{4}$ http://www.imd.org/wcc/research-methodology
} 
the paper concludes summarising the main findings and discussing its implications regarding the future design of the ENP.

\section{THE EUROPEAN NEIGHBOURHOOD POLICY}

One of the objectives of the ENP is to promote political and institutional changes towards democratic governance and market liberalisation, a process that at the same time is understood as a tool for economic development and convergence in neighbouring countries. As highlighted by Wesselink and Boschma (2015), after the fifth enlargement round of the European Union (EU) in 2004 its external borders shifted drastically. Suddenly a range of poorer, economically and politically less stable and less democratic countries bordered the EU. In response to these changing circumstances, the need was felt to create a unified policy towards the countries bordering the EU. The goal of this new unified policy would be to create a ring of friendly, stable and prosperous countries around the European Union in order to guarantee stability along the outer borders of the EU. The new policy would not offer accession perspective for these countries, as had been done before in order to drive reform in neighbouring countries. However, the policy would promote close political cooperation, close economic integration and ultimately access to the unified market, as a reward for convergence towards the EU 'Acquis' on economic regulations and progress in the areas of border security, prevention of illegal migration, an improved human rights record and expanded efforts towards democracy.

Although the core focus of the ENP is on trade and economic reforms, migration policies, institutional reform and collaboration in research and higher education are also part of the ENP, and all these elements are meant to contribute to the ultimate goal of creating a ring of stable, friendly and prosperous countries around the EU (Com 393 final, 2003). The bulk of the ENP is bilateral. The ENP and the EU-Russia strategic partnership cover 17 countries. Apart of Russia, the ENC fall into two regional groups: The ENPEast countries (Armenia, Azerbaijan, Belarus, Georgia, Moldova and Ukraine) and the ENP-South countries (Algeria, Egypt, Israel, Jordan, Lebanon, Libya, Morocco, the occupied Palestinian territory, Syria and Tunisia). The ENP is a differentiated policy in which each country is supported to reform in its own speed, and with its own priorities. Based on specific country reports, action plans were negotiated that describe key priority areas for policy reforms (see table 1). The first action plans were mutually recognized in February 2005. Based on these action plans, the EU has also drafted a strategy paper for almost each country for the 2007-2013 budget framework, and indicative programmes for the 2007-2010 and 20112013 period. Russia was also asked to participate in the ENP, but in subsequent negotiations it was decided that a separate policy instrument would be developed to guide Russian-European foreign policy (COM 393 final, 2003). This separate policy instrument, called the EU-Russia strategic partnership, has similar goals to the ENP and is funded through the same funding instrument.

Up to now, the EU does not yet have action plans for four of the ENC: Libya, Syria, Belarus and Algeria. In the first three countries the main reason is that, a basic level of democracy and human rights is required 
before incorporation in the ENP can take place. Algeria and the EU are still in negotiations over the ratification of an action plan.

\section{[TABLE 1. ABOUT HERE]}

The evidence on the impact of the ENP on the economic, institutional and social development of the EU neighbouring countries is scarce. Previous research produced within the SEARCH project ${ }^{5}$ has found that the speed of the process of convergence of institutional quality towards European norms and values is still slow, although some progresses have been registered. In fact, according to Harpaz (2014), the results of the ENP on the eve of its tenth anniversary are much less impressive and the initial high hopes for a comprehensive and systematic legislative and regulatory alignment have not been realized institutional, social and cultural factors are central elements to consider when analysing social and economic dynamics in ENC. These results are mainly based on three particular analyses. First, Bartlett et al. (2013) analyse the link between economic growth and institutional reform in the ENC. Their results show that the ENC have a weaker institutional convergence to the EU than candidate countries. For them, the main reason is that the EU has not yet played an important role as a "transformative power", shaping faster institutional convergence and there is a danger that the reform processes will either stagnate or "run out of steam" if the EU does not take a more decisive role in the process. Second, Hlepas (2015) have analysed whether or not institutional quality has converged across countries and the influence of this process on ENC's competitiveness. The obtained results are in line with the ones obtained by Čučković et al. (2015) suggesting that the impacts of the ENP have been relatively modest. Revilla-Diez et al (2013) argue that there are several reasons why the ENP post-communist economies lag behind as compared to the high performing Asian countries that outstrip competitors in terms of economic growth. The most relevant one seems to be that post-socialist states did not manage to effectively change the institutions of the old regime for the new efficient ones. Moreover, even the minor institutional changes incorporated failed to work due to the lost faith in the state and the absence of fit with the existing informal institutional environment. Last, Varga and Baypinar (2016) have used a CGE model to analyse the impact of a technology-based development policy in a Turkish region that can be representative of the average ENP region. Their results show that these policies can produce sustainable long-run impacts in the considered countries.

Taking into account these previous studies, the contribution of this paper is twofold: first, we analyse the relative performance of ENC compared to a wide sample of economies not focusing on a single aspect, but looking at different dimensions; and, second, we analyse the regional differences in these dimensions through the comparison of ENC with a wider sample of economies controlling for the different timing of the adoption and implementation of the ENP.

\section{METHODOLOGICAL ISSUES: DEFINING THE ISEPI INDEX}

\footnotetext{
${ }^{5}$ http://www.ub.edu/searchproject
} 
As Booysen (2002) argues, one can classify and evaluate indicators according to a number of general dimensions of measurement. Obviously, all the process is affected by the objective wanted to cover with the indicator. Once defined it, we should focus on the technique and method dimension to be used. The first decision involves the selection of variables and components. The selection is generally based on theory, empirical analysis, pragmatism or intuitive appeal, or some combination thereof.

In our case, we are obliged to work with a large set of data, first, because we might capture a huge variety of dimensions (and sub-dimensions) in the framework of the Index (to consider economic, social, institutional issues and sub-components). Second, due to the high number of countries and variables that differed widely in terms of units of measurement, and in statistical characteristics. We are therefore obliged to use a highly flexible method in order to account for all possible dimensions of the Institutional, Social \& Economic Performance of the considered countries. Considering this, we will follow the proposal by Liu (1978). The main idea is to build a composite index using intermediate indexes computed using basic data or other indexes. The index structure and variable weights are chosen a priori based on expert judgement.

Taking this into account, our approach to analyse the Institutional, Social and Economic performance of considered countries is to elaborate a composite index (ISEPI from now on). The ISEPI index is built from 51 variables comprising both hard and soft data (see figure 1) and it comprises the following seven main sub-indexes that try to consider identified, measurable, and comparable socioeconomic aspects that are relevant from a global perspective ${ }^{6}$ :

- Macroeconomic environment (D1): this first sub-index measures the economic environment of the country. It takes into account GDP growth, labour, public accounts, investment, international trade, and financial issues.

- Costs and prices (D2): this sub-index considers different variables related to prices and costs: Consumer prices, labour costs, hourly wages, cost of live and exchanges rate.

- Productivity and human capital (D3): in this sub-index we summarise different aspects related to labour productivity and the level of human capital of every country: schooling levels, availability of qualified workers, among others.

- Technological and innovative capacity (D4): this sub-index covers the aspects related to the technological capacity of the country as well as the efforts to improve it. Therefore, we take into account the technological capacity as well as different measures of technological adoption.

- Market potential (D5): The last sub-index captures the potential of a country from an economic point of view covering demand in terms of population and growth potential.

- Quality of life and labour market conditions (D6): this sub-index captures life expectancy, quality of live, working conditions (workers motivation and hours of work), and security (personal security and private property protection).

\footnotetext{
${ }^{6}$ Groh and Wich (2012).
} 
- Business-friendly environment (D7): this sub-index covers aspects related to factors helping or hindering business activity in a country. So, we take into account the quality of infrastructures, different measures of investment risks, administrative burdens, barriers to international trade and taxes on firms.

While the first five dimensions are related to the economic performance of the considered countries, the two last dimensions are much more related to the social and institutional dimensions. The selection of the variables to be considered in each of the dimension has been chosen taking into account, on the one hand, the theoretical linkages between the indicators and the concepts we wanted to proxy, and on the other hand, data availability both in terms of countries and years. In this sense, the list of factors to be considered in each dimension have been selected taking into account the analysis in Sala-i-Martín et al. (2014) and Garelli (2014), trying to avoid duplicities and giving priority to those indicators with higher availability.

The list of considered countries can be found in table A.1. of the appendix while the exact definition and the data sources used for each of the 51 considered indicators can be found in table A.2. of the appendix. Several databases have been used: the World Bank World Development Indicators, the World Investment Report by the United Nations Conference on Trade and Development, The International Institute for Management Development datasets and additional variables from the Conference Board and The World Economic Forum datasets. The period considered is 1995-2013. We have computed the ISEPI index for a wide sample of economies: the most competitive economies according to the World Economic Forum, the members of the European Union (with the only exception of Croatia that entered the EU in middle 2013), and several developing and emerging economies, that constitute an interesting "control” group for ENC during this period. The final sample of countries is formed by a set of 76 countries.

\section{[FIGURE 1. ABOUT HERE]}

Once we have compiled the data for the 51 simple indicators, in order to build the index, we apply the statistical method by Royuela et al. (2003), López-Tamayo et al. (2013) and Murillo et al. (2015) following the proposal by Liu (1978) in the context of quality of life indicators. This procedure was built taking into account several premises that we have adapted to the peculiarities of the ISEPI in the following way:

1. The index has to be able to aggregate base indicators measured in different units.

2. The aggregation process has to be able to compare the indicators with a high level of different relative dispersion.

3. The index has to allow the construction of a scale that lets the data talk, i.e., that reflects the statistical characteristics of the data.

4. The final index has to allow for a comparison over time: when a system's basic variables rise, the final index has to increase.

5. If the relative size of the systems changes over time, the index has to condense this information without overvaluing (undervaluing) the result for a specific system. 
These criteria are the basis for our index, $I$, as a linear function of several, $K$, Institutional, Social \& Economic attributes $(X)$. The final index is obtained as an arithmetic average of the different sub-indexes. So,for example, in order to obtain the sub-index D3 (Productivity and human capital), we combine the following seven attributes (K=7): Labour productivity (GDP per worker, v18), Public expenses in education as a percentage of GDP (v19), Share of population between 25 and 34 years old with secondary studies (v20), Share of population between 25 and 34 years old with tertiary studies (v21), Researchers in firms /1000 inhabitants (v22), Qualified workforce available (v23) and Entrepreneurship (v24).

Each attribute, $X_{f}$, is originally measured in its own units, but needs to be redefined and homogenised. We do so taking a relative measure, which converts the result into a percentage. If country $i$ has a value in the $f$ attribute equal to $X^{i}$, then we say that we can measure how far country $i$ differs from the global average in terms of the attribute merely by computing:

$$
Y_{f}^{i}=X_{f}^{i} / \bar{X}_{f}
$$

Then, the final index, $I^{\prime \prime}{ }^{i}$, is a linear function of the attributes' vector $Y^{i}, Y^{i}=\left(Y_{1}{ }^{i}, \ldots, Y_{K}{ }^{i}\right)$ :

$$
I^{\prime \prime, i}=Y^{i} * W
$$

where $W=\left(w_{1}, \ldots, w_{K}\right)$ are the weights given to every attribute. The determination of the weights is clearly an important point. However, no perfect solution exists and even if weights are fixed according to previous studies or expert judgements, they will not escape criticism (OECD, 2008). Thus, so as to minimize this and to avoid being subjective, the methodological solution adopted here is to give the same relative weights to the critical factors deemed relevant for the calculation of our index (although taking into account the direction of the effect, positive or negative, on the considered dimension) ${ }^{7}$. The robustness of the results to this methodological decision has been checked using multivariate analysis. In particular, we have use principal component analysis to look at the proportion of the variance explained by the first component extracted from the variables related to each dimension and we have also checked that the weights and signs are in line with the theoretical predictions summarised in figure 1. The results, which are available from the authors on request, confirm the validity of our approach for the seven sub-indexes.

Once (2) has been calculated, differences between countries can be expressed in a dispersion measurement, for example the variance $\operatorname{VAR}\left(I^{\prime \prime}\right)$ from $i=1$ to $\mathrm{N}$, where $\mathrm{N}$ is the total number of countries. We understand that this variance is useful information about attribute $Y_{f}$. If we only had one attribute for Productivity and human capital, then the measurement of this sub-index would be defined by this particular variance. But as

\footnotetext{
${ }^{7}$ As noted by an anonymous referee, equal weighting together with the linear aggregation rule imply that all indicators are perfect substitutes. This means that a decrease of one point in a sub-index can be compensated by a similar increase in another sub-index. The implications of the assumption of compensability has been in-depth analysed by Munda and Nardo (2009).
} 
there is more than one attribute in each index, a general measurement for each aggregate index needs to be defined. Following (2), the total amount of information considered in the sub-index is the following weighted variance and covariance matrix of the attributes:

$$
\operatorname{var}\left(I^{\prime \prime}\right)=\operatorname{var}(Y * W)=W^{\prime} * \operatorname{var}(Y) * W
$$

Nevertheless, if the sub-index is calculated just as $I^{\prime \prime}=Y W$, then the attributes with greater variance are overweighted. This effect can be seen in one example. If in the Productivity and human capital subindex, a country has a good position in six of the seven attributes, but is badly placed in the other (perhaps due to the fact that this attribute has a much higher variance than the others) the final result will be poor. In order to avoid this, we should compute the index as:

$$
I^{\prime}=Z * W
$$

where $Z_{f}$ are the standardised variables: $Z_{f}=\left(X_{f}-\bar{X}_{f}\right) / s d\left(X_{f}\right)$. We can expect the variance of that index to be equal to one. But if there is information common to these attributes, we have:

$$
\operatorname{var}\left(I^{\prime}\right)=W^{\prime} * R * W,
$$

where $R$ is the correlation matrix between the standardised attributes. This is the reason for computing the final standardised positions (number of standard deviations away from the trend) of all countries as:

$$
I=(Z * W) /\left(W^{\prime} * R * W\right) .
$$

Next, we add the variance-covariance matrix to the standardised positions of all countries defined in (6). So, the final index for the Human capital and productivity dimension is:

$$
I 3=100 *\left(1+I *\left[W^{\prime} * \operatorname{var}(Y) * W\right]\right) .
$$

In order to make it more comprehensible we have included a level to the final measurement (100 in the base year). The methodology described, then, gives the relative position that a country has in the whole group of analysed countries. However, we have also considered the possibility of computing an increase or decrease in the sub-index over time. In this case, we have to take a base period. In this base period the country average will be equal to 100 . So the temporal analysis will compare the relative position of a country in any variable in year $K$, with the base period average of all countries involved in the analysis:

$$
Z_{i}^{K}=\frac{X_{i}^{K}-\bar{X}^{00}}{S_{x}^{00}}
$$


Therefore, we are measuring the relative position in terms of the base year standard deviation. The dispersion of all variables can also be higher or lower through time. As in any index number, the choice of the base year will be very important, but will also be completely arbitrary. And as we go further from the base year, the comparisons will lose some of their value. This is because the scale that we are using depends on the base year. Nevertheless, the base year can be changed without a great deal of work.

This procedure applied to this particular sub-index has been replicated for the other dimensions and the final index, the ISEPI, is calculated as an arithmetic average of the seven sub-indexes.

The final question that has to be addressed in the ISEPI deals with the different population size of countries and its evolution. These changes may affect both the basic measurements of the index structure (mean and variance) and the aggregation of countries in systems and subsystems. As discussed by Royuela et al. (2003), there are two options to introduce country weights in the calculation of the composite indicator: the Laspeyres and the Paasche indexes. However, the former would not consider the change in population of each country but only the population in the base year (1995). For this reason, we have used the Paasche index as it will consider population changes from 1995 to 2013 in the elaboration of the indicators. Taking this into account, we can technically define the ISEPI as a weighted (a priori) arithmetic average index of partial indicators that express the relative standardised position of every individual (country, subsystem or system) after combining the variability of all variables, with a Paasche type temporal aggregation. The index allows for comparisons between countries (or other major territorial aggregations) in each period and over time, taking the global average in 1995 as 100. As mentioned above, changing the base year would cause a change in the definition of the measurement of economic performance. If we compute an index number with 2000 as our base year the comparison will be done using the ISEPI definition of 2000, and it will not be the same as it was in 1995. Taking this into account, and in order to facilitate time and crosscountry comparisons, we did a last transformation to the different index using a continuous scaling method. Continuous scaling method is based on linear interpolations to normalize indexes to lie within a particular scale (see Ochel and Röhn, 2006). In a first step, the distance from best and worst performer is used to transform the sub-indexes into a range between 0 and 1 and in a second step, these values are normalized to lie within a range of 0 and 7 . This last step is done only for illustrative purposes and it does not influence the ranking as this method retains the relative distances between the original values. As this procedure is only applied to the different subindexes and not to the underlying simple indicators, the outlier problem is minimised. These are the values that are shown and described across the paper.

\section{RESULTS}

\subsection{Descriptive evidence}


The rankings obtained for 2013 and 1995 are shown in Tables 2 and $3^{8}$. Table 2 shows regional rankings according to the ISEPI values and its seven dimensions in 1995 and 2013 and the change in the index between the two considered periods. As we can see from this table 2, in 2013 the average value of the ISEPI for developed and EU countries is clearly above the average (4.09 and 3.64, respectively compared to 3.13). These two groups of countries show also the higher values for nearly all dimensions, with the exception of cost and prices and market potential. The evolution between 1995 and 2013 is also positive for these two group of countries in nearly all dimensions. The only exception is business-friendly environment for the developed economies where there is slight decrease in the sub-index for this dimension.

\section{[TABLE 2. ABOUT HERE]}

Focusing now on ENC countries, we can see that the overall evolution has been positive in the three groups, ENC-East, ENC-South and Russia, but it has been much more intense in Russia where all the sub-indexes except productivity and human capital have experienced a strong increase during the period. In aggregate terms, the evolution of ENC-East and ENC-South countries have been very similar to that experienced by emerging economies and clearly better than the other developing economies considered in our study. While ENC-East countries have performed quite well in several dimensions (particularly in the macroeconomic environment and technological and innovative capital), they have lost positions regarding quality of life and labour market conditions together with business-friendly environment. This is a relevant result as one of the objectives of the ENP was precisely to improve the social and institutional environment in neighbouring countries. In the case of ENC-South the situation is even worst as only minor improvements are achieved in a few dimensions (the only exception is productivity and human capital where the score is significantly higher in 2013 compared to 1995) and the situation has worsened in cost and prices, market potential, quality of life and labour market conditions, and business friendly environment.

Table 3 shows detailed information at the country level for the ISEPI indicators. In particular, it shows the value of the ISEPI index in these two years, together with the relative positions of each country within the whole sample of considered countries and within its particular group. In the last column, we also show the change between 1995 and 2013 and the variation in relative positions for the global and the regional ranking. Although due to space limitations we cannot extend here on the description of the seven subdimensions of the ISEPI for the 76 considered countries for 1995 and 2013, table A.3. of the appendix provides detailed information on the values of the indexes and the rankings.

\section{[TABLE 3. ABOUT HERE]}

Starting with developed countries, we can see that Singapore was in the first position of the global ranking both in 1995 and in 2013 with a slightly improved position in terms of the ISEPI score. In 2013, Switzerland

\footnotetext{
${ }^{8}$ The correlation of the ISEPI index with GDP per capita for the 76 analysed countries is 0.73 , with the Human Development Index 0.82, with the World Economic Forum Global Competitiveness Index is 0.89 (common sample of 75 countries) and with the IMD Competiveness index is 0.84 (common sample of 54 countries).
} 
is the second developed economy, although it is placed in the eight position in the global ranking. This was exactly the same position in 1995 although it has increased its position within the region. All countries within this group have improved their scores between 1995 and 2013, although in the United States and Australia, the variation is very close to zero. In fact, together with Japan and Canada, these four countries have fallen in the global ranking between 1995 and 2013.

The next group of countries shown in the table are the members of the European Union. The countries in the first positions are Luxembourg, Sweden, Finland, Denmark and the Netherlands. The top positions in the regional ranking have been fairly stable between 1995 and 2013, with the only exception of Luxembourg that has experienced a very important improvement during the period. In the middle positions of this group, we find the rest of old members of the EU and Mediterranean countries where the impact of the recession has been much more relevant that in Northern Europe. Next, we find the Central and Eastern European countries that have joined the EU in a latter stage. Some countries such as Estonia Lithuania and Poland have significantly increased their performance according to the ISEPI between 1995 and 2013, while others such as Cyprus, Slovakia or Bulgaria are now in a worst relative position.

Moving to ENC, we can see that the country evolution is quite heterogeneous within the different subgroups. In particular, and starting with ENC-East, we can see that Georgia, Azerbaijan and Armenia have improved their relative situation both within the region and in the overall ranking, where they jump more than 10 positions between 1995 and 2013. However, Moldova, Belarus and Ukraine have performed worst than them. The case of Russia is impressive and has already been described when looking the results in table 2. It has improved in more than 25 positions during the period. Moving to ENC-South, the case of Israel is clearly different than the rest of countries in the region. It has a value of the ISEPI that is above the developed countries average and it has even increased during the period improving 8 positions in the global ranking. After Israel, we find Jordan, Palestine, Lebanon, Libya, Tunisia, Morocco, Egypt, Algeria and Syria. The internal ranking has been very stable except for the case of Syria that has lost 5 positions during the considered period. It is worth mentioning that nearly all countries have lost positions in the world ranking with the only exception of Morocco that has gained 10 positions in the overall ranking.

Figure 2 provides a more detailed picture of the evolution of the ISEPI in ENC countries. As we can see from this figure, internal differences between ENC-East countries have decreased and it is clearly appreciated the clear improvement of Russia, and the change in the positive trend of Moldova, Belarus and Ukraine. When looking at ENC-South, Israel is clearly the top performer with a positive trend during the considered period. The rest of countries have shown a stable path, with the only exception of Syria that has clearly worsened. Internal differences within this group are increasing, mainly due to the impact of the diverging trends of Israel and Syria.

[FIGURE 2. ABOUT HERE] 
Last, and coming back to the results in table 3, the evolution of emerging and developing countries is quite heterogeneous with countries such as Turkey or Kazakhstan showing a clearly positive trend and others like Philippines, Argentina, Peru, Iran or Senegal where the situation has clearly worsened.

\subsection{Has a convergence process taken place in the different ISEPI dimensions?}

In this sub-section, we analyse whether a convergence process in the ISEPI and its seven sub-index has been observed since mid-nineties. We start with an unconditional $\beta$-convergence analysis running the following a la Barro and Sala-i-Martin (2003) regression:

$$
g_{i}=\alpha+\beta I_{0, i}+\epsilon_{i} .
$$

Where $g$ denotes the growth rate between 1995 and 2013 of the considered index, $I_{0}$ represents its initial value and $\epsilon_{i}$ is an error term capturing common transitional shocks for all countries. The parameter $\beta$ captures the speed of convergence into a unique steady-state which is assumed to be common to all countries involved in the analysis. In order to evaluate if convergence to a country-specific steady-state is observed in the considered period, we have run the following conditional $\beta$-convergence regression for the ISEPI and the different sub-indexes:

$$
g_{i t}=I_{0, i t} \beta+X_{0, i t} \gamma+Z_{i}+T_{t}+\epsilon_{i t} .
$$

Where $g_{i t}$ represents the annual growth rate, $I_{0, i t}$ the initial values of each index, $\mathrm{X}_{0, i t}$ is a matrix with the variables conditioning the convergence process (including two dummy variables that capture whether the ENP has been driven by a plan or a contract), $Z_{i}$ and $T_{t}$ denote, respectively country and time specific fixed effects and, last, $\epsilon_{i t}$ is a random error term.

First of all, regressions (9) and (10) have been estimated omitting time fixed effects (top part of table 4). As it can be seen, the $\beta$ parameter is significant and negative in all cases, showing that, for the global index and for each of its dimensions, a conditional convergence process has occurred during the considered period. As previously mentioned, conditional convergence is defined as the existence of an inverse relationship between the initial level of the analysed variable its subsequent growth once the determinants of the steady state level of the variable are controlled for. In our case, countries with low levels of the steady state of the ISEPI (or the different subindexes) do tend to grow more rapidly, but, however this does not mean that all countries in each group are converging to the same steady state: it only implies that they are converging to their own steady states. While under the unconditional convergence, differences would be transitory, conditional convergence implies that differences may be permanent due to cross-country structural factors. A part of country fixed effects, it is interesting to see the results regarding other conditioning variables. In particular, when the ENP has been adopted by means of a plan, only in the case of D4 --Technological and innovative capacity - and D5 -Market Potential- we find a positive effect, although in this modelling framework it is not possible to establish a causal impact of the policy. However, 
it is worth mentioning that in case of dimension D1 -Macroeconomic performance- a plan is associated to a lower growth in the considered dimension. In case ENP has been conducted by a contract, dimension D1 -Macroeconomic Environment- and dimension D7 - Business friendly environment - a positive coefficient is found while in D5 - Market Potential- and D6 - Quality of life- a negative coefficient is found. None effect is detected in the other sub-indexes as well as in the global ISEPI index. If those common shocks that could have affected to all the economies are isolated by time fixed effects (bottom part of table 4), the results do not change in a significant way. These results are interesting as in this modelling framework, the impact of the crisis (understood as a global common shock) is controlled by including time fixed effects in the specification. We can see that the $\beta$-parameter shows the same convergence process as before and the results regarding the ENP proxied by having a plan or a contract remain similar with the only exception of D7 - Business friendly environment- where the coefficient is now not statistically significant at the usual levels.

\section{[TABLE 4. ABOUT HERE]}

\section{FINAL REMARKS}

In this article, we have analysed the macroeconomic, social and institutional evolution of ENC in a comparative perspective. We have built a multi-dimensional index and we have analysed the regional differences in the different dimensions of the index in order to provide an assessment of the recent evolution of ENC in comparative terms.

We have also have estimated convergence equations for the composite indicator and its seven dimensions using panel regressions. Our results have have found evidence of conditional convergence over the considered period that are in line with previous works such as Rodriguez-Pose and Tselios (2015) regarding economic and social factors and Savoia and Sen (2013) or Hall (2015) regarding institutions.

The analysis has controlled for the potential effects of the ENP, a bilateral policy between the countries and the EU promoting political and institutional changes towards democratic governance and market liberalisation, a process that at the same time has been understood as a tool for economic development and convergence in neighbouring countries. When including country fixed-effects and ENP related variables, the obtained results confirms that different short-run conditions can change the path towards the steadystate. In fact, the existence of convergence towards each country's steady state within the different dimensions considered does not necessarily imply that these higher transitional growth rates (higher speed of convergence) are associated to improvements in each individual country (each steady-state), but to shortterm corrections and similar policy responses to the common economic shock that the different groups of countries have experienced. The results on conditional convergence also suggest that sharing the same structural characteristics could significantly enhance the 'catch-up' amongst countries in the different dimensions. In fact, the obtained evidence is clearly favourable to this hypothesis and it can be understood as justifying the need to reinforce bilateral action plans that have characterized ENP recognising the 
different starting point and particular characteristics of each neighbouring country if the policy objective is to reduce cross-country differences in the area and promote convergence to the EU. These results are in line with previous findings, but, however, further research will be needed to understand the channels through which institutional change associated to the ENP could enhance economic growth in the area.

\section{REFERENCE LIST}

Crescenzi, R., Luca, D., Milio, S. (2016). The geography of the economic crisis in Europe: national macroeconomic conditions, regional structural factors and short-term economic performance, Cambridge Journal of Regions, Economy and Society, 9 (1), pp. 13-32.

Čučković, N., Kersimir, J. Bartlett, W. (2015). A Comparative Perspective on Institutional Quality in the European Neighbourhood. Tijdschrift voor economische en sociale geografie / Journal of Economic and Social Geography, forthcoming.

Booysen, F. (2002). An overview and evaluation of composite indices of development, Social Indicators Research, 59, 115-151.

Çolak, M.S., Ege, A. (2013). An Assessment of EU 2020 Strategy: Too Far to Reach?, Social Indicators Research, 110 (2), pp. 659-680.

Didier, T., Hevia, C., Schmukler, S, K. (2012). How resilient and countercyclical were emerging economies during the global financial crisis?, Journal of International Money and Finance, 31 (8), pp. 2052-2077.

Dudzińska, K. (2013). The Baltic States' Success Story in Combating the Economic Crisis: Consequences for Regional Cooperation within the EU and with Russia, PISM Policy paper 6 (54). Available at https://www.pism.pl/files/?id_plik=13084

European Commission (2009), Impact of the global crisis on neighbouring countries of the EU, European $\begin{array}{lllll}\text { Economy } & \text { Occasional } & \text { Papers } & \text { Available }\end{array}$ http://ec.europa.eu/economy_finance/publications/publication15398_en.pdf

Fatas, A., Mihov, I. (2009). The 4 I's of Economic Growth. INSEAD, Available at http://faculty.insead.edu/fatas/wall/wall.pdf

Garelli, S. (2014). The Fundamentals and History of Competitiveness. In IMD World Competitiveness Yearbook (pp. 488-503).

Giambona, F., Vassallo, E. (2014). Composite Indicator of Social Inclusion for European Countries, Social Indicators Research, 116 (1), pp. 269-293. 
Groh, A. P. Wich, M. (2012). Emerging economies' attraction of foreign direct investment, Emerging Markets Review, 13 (2), pp. 210-229.

Hall, J. C. (2015)., Institutional Convergence: Exit or Voice?, West Virginia University Department of Economics Working Paper 15-4. Available at http://www.be.wvu.edu/phd_economics/pdf/15-40.pdf

Harpaz, G. (2014). Approximation of Laws under the European Neighbourhood Policy: The Challenges that Lie Ahead, European Foreign Affairs Review, 19 (3), pp. 429-452.

Hlepas, N. (2015). The Quality of the National Institutional Environment of EU and Neighbouring Countries in Comparative Perspective, in: Javier Albarracín (ed.), SEARCH Research and Assessment on Euro-Mediterranean Relations, Documents 10 IEMed, European Institute of the Mediterranean, Barcelona, pp.193-230.

Lopez-Tamayo, J, Royuela, V. and Suriñach J. (2013). Building a “Quality in Work” Index in Spain. In Sirgy, M. Joseph, Phillips, Rhonda, Rahtz, Don (Eds.). Community Quality-of-Life Indicators: Best Cases VI (pp. 233-262). Springer Science+Business Media.

Liu, B.C. (1978). Variations in social quality of life indicators in medium metropolitan areas. American Journal of Economics and Sociology, 37 (3), 241-260.

Mitra, S. (2013). Towards a Multidimensional Measure of Governance, Social Indicators Research, 112 (2), pp. 477-496.

Munda, G. and Nardo, M. (2009). Noncompensatory/nonlinear composite indicators for ranking countries: a defensible setting, Applied Economics, 41 (12), 1513-1523.

Murillo, J., Romaní, J., Suriñach, J. (2015). The Business Excellence Attraction Composite Index (BEACI) in small areas. Design and application to the municipalities of the Barcelona province, Applied Economics, 47 (2), pp. 161-179.

Ochel, W., Röhn, O. (2006). Ranking of Countries-The WEF, IMD, Fraser and Heritage Indices., CESifo DICE Report, Vol. 4, pp. 48-60,

OECD (2008), Handbook on Constructing Composite Indicators. Methodology and User Guide. Available at http://www.oecd.org/std/42495745.pdf

PWC (2015), The World in 2050. Will the shift in global economic power continue?, Available at https://www.pwc.com/gx/en/issues/the-economy/assets/world-in-2050-february-2015.pdf 
Revilla-Diez, J., Schiller, D., Zvirgzde, D. (2013). Similarities and differences of institutional change between ENP countries and other catch-up countries. SEARCH WP5.14. Available at

http://www.ub.edu/searchproject/wp-content/uploads/2013/01/WP-5.14.pdf

Rodríguez-Pose, A., Tselios, V. (2015). Toward Inclusive Growth: Is There Regional Convergence in Social Welfare?, International Regional Science Review, 38 (1), pp. 30-60.

Royuela, V., Suriñach, J., Reyes, M. (2003). Measuring quality of life in small areas over different periods of time. Social Indicators Research, 64 (1), pp. 51-74.

Sala-i-Martín, X., Bilbao-Osorio, B., Blanke, J., Drzeniek-Hanouez, M., Geiger, T., Ko, C. (2014). The Global Competitiveness Index 2013-2014: Sustaining Growth Building Resilience in WEF Global Competitiveness Report 2013-2014, Chapter 1.1., pp. 3-52.

Savoia, A., Sen, K. (2012), Do We See Convergence in Institutions? A Cross-Country Analysis, Development Economics and Public Policy Working Paper Series WP No. 33/2012. Available at http://www.seed.manchester.ac.uk/medialibrary/IDPM/working_papers/depp/depp_wp33.pdf

Smits, J., Steendijk, R. (2015). The International Wealth Index (IWI) Social Indicators Research, 122 (1), pp. 65-85.

Varga, A., Baypinar, M. B. (2016). Economic impact assessment of alternative European Neighborhood Policy (ENP) options with the application of the GMR-Turkey model, Annals of Regional Science, 56 (1), pp. 153-176.

Wesselink, E., Boschma, R. (2015). European Neighbourhood Policy: History, Structure, and Implemented Policy Measure, Tijdschrift voor economische en sociale geografie / Journal of Economic and Social Geography, forthcoming.

World Economic Forum (2011). Scenarios for the Mediterranean Region, Available at http://www3.weforum.org/docs/WEF_Scenario_MediterraneanRegion_Report_2011.pdf

World Economic Forum (2013). Scenarios for the Russian Federation, Available at http://www3.weforum.org/docs/WEF_Scenarios_RussianFederation_Report_2013.pdf

Wu, P. C., Fan, C. W., Pan, S. C. (2014). Does Human Development Index Provide Rational Development Rankings? Evidence from Efficiency Rankings in Super Efficiency Model, Social Indicators Research, 116 (2), pp. 647-658. 


\section{FIGURES}

Figure 1. Structure of the Institutional. Social and Economic Performance Index (ISEPI). 


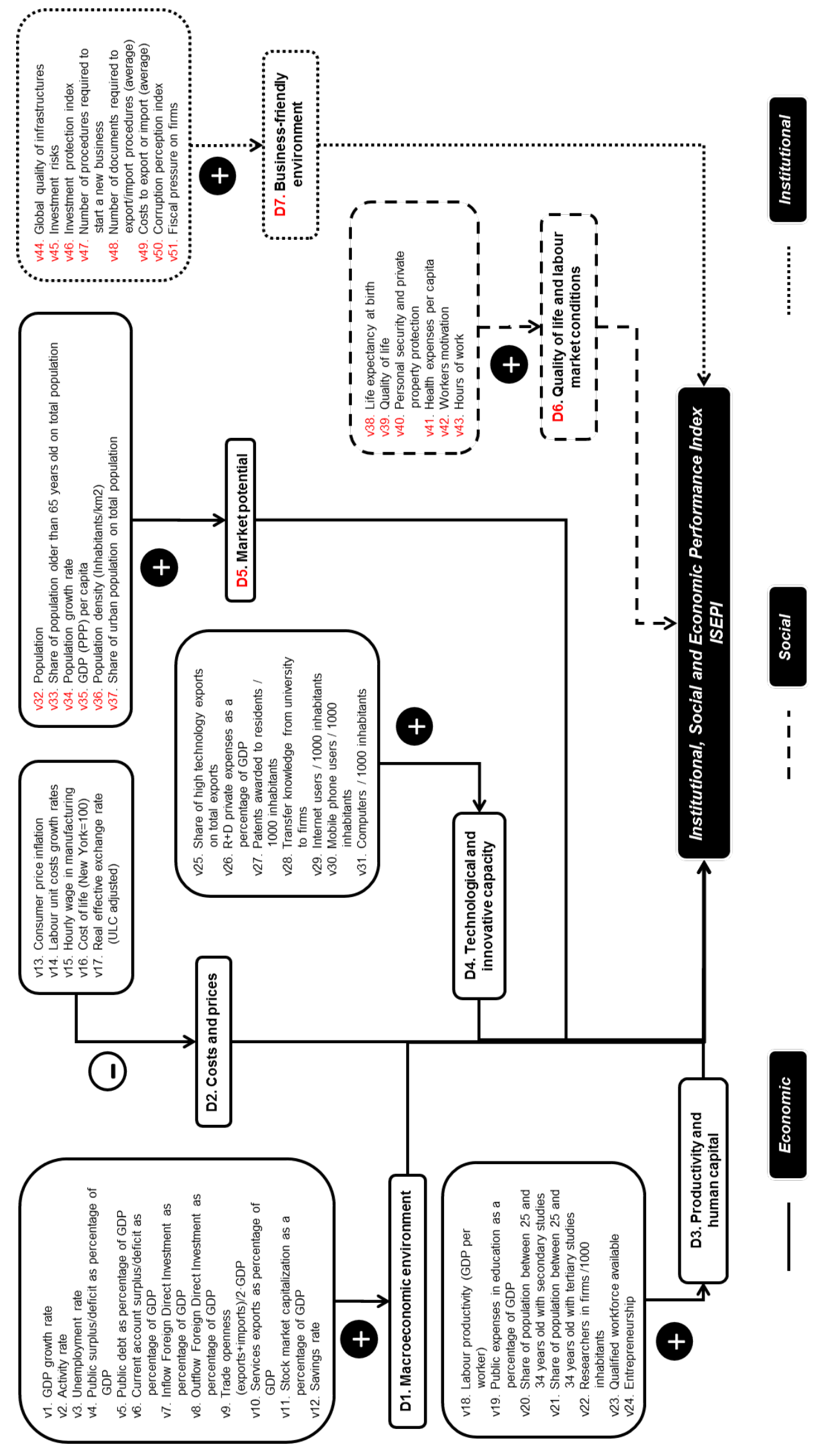


Figure 2. Evolution of the ISEPI in ENC.
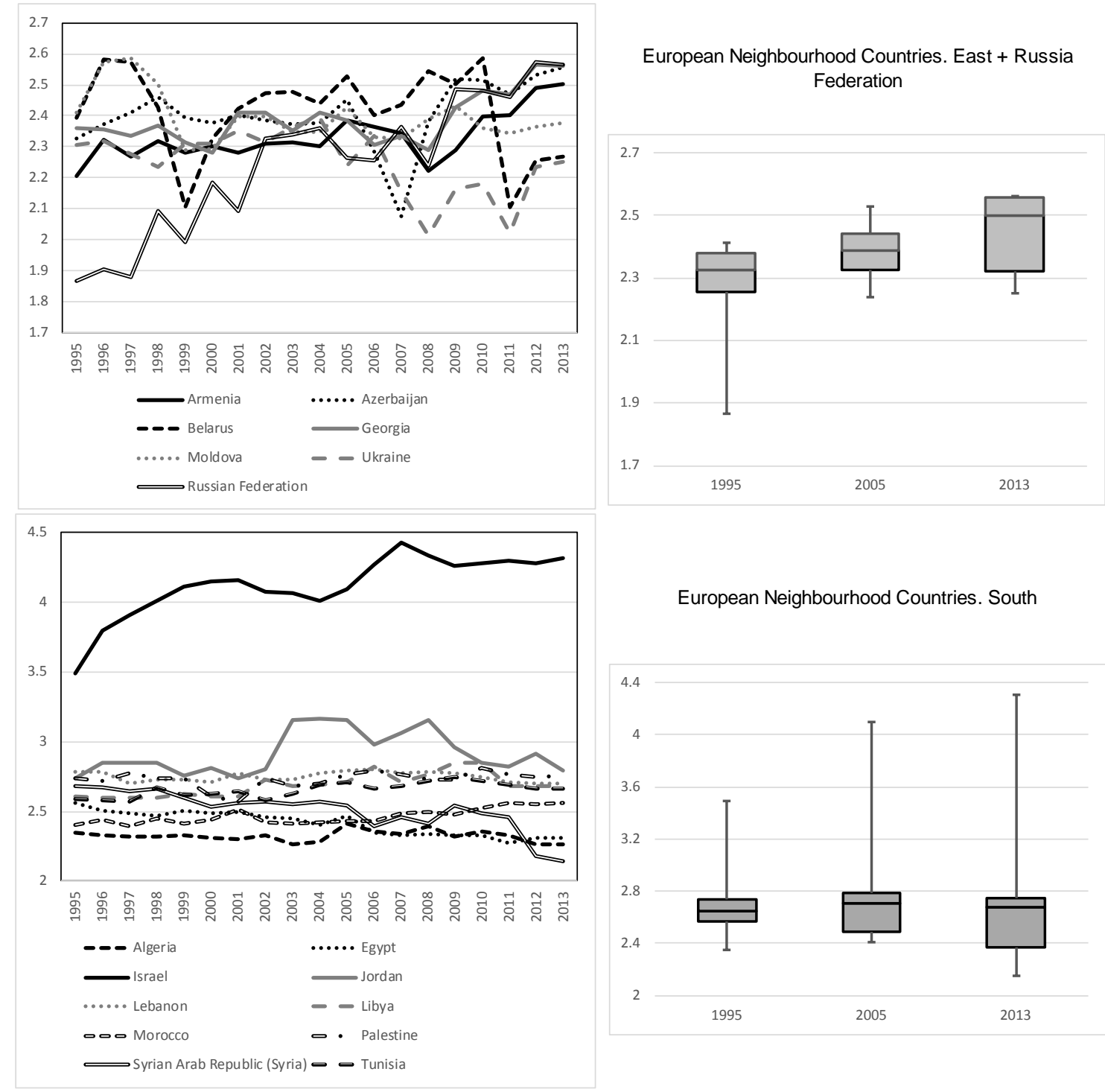

European Neighbourhood Countries. South

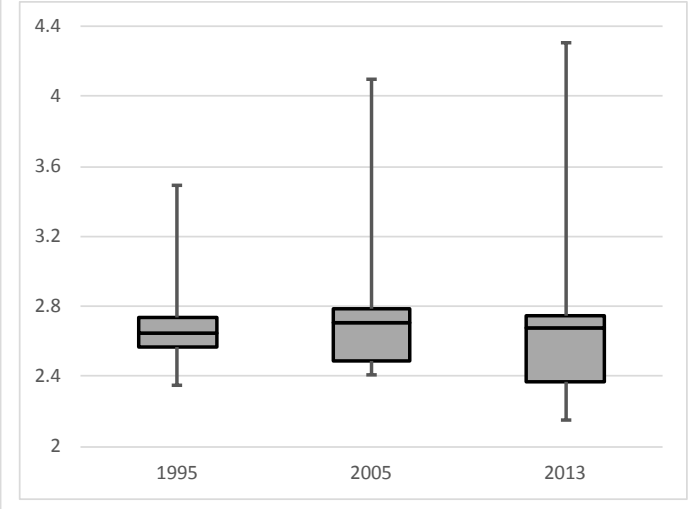




\section{TABLES}

Table 1. Overview of countries that are part of the ENP.

\begin{tabular}{|c|c|c|c|c|c|}
\hline Region & Country & $\begin{array}{l}\text { Initial EU Contract } \\
\left(\mathrm{PCA}^{[1]} \text { or } \mathrm{AA}^{[2]}\right) \\
\end{array}$ & $\begin{array}{l}\text { Ratification } \\
\text { Action Plan } \\
\end{array}$ & $\begin{array}{l}\text { CFSP } \\
\text { invitation }^{[3]} \\
\end{array}$ & $\begin{array}{l}\text { FTA } \\
\text { provisions }^{[4]}\end{array}$ \\
\hline \multirow[t]{6}{*}{ ENC-EAST } & Armenia & July 1999 & November 2006 & Yes & Yes \\
\hline & Azerbaijan & July 1999 & November 2006 & Yes & Yes \\
\hline & Belarus & No negotiations until human rights situation improves & & No & No \\
\hline & Georgia & July 1999 & November 2006 & Yes & Yes \\
\hline & Moldova & July 1998 & February 2005 & Yes & Yes \\
\hline & Ukraine & March 1998 & February 2005 & Yes & Yes \\
\hline RUSSIA & Russia & December 1997 & Roadmap adopted may 2005 & No & No \\
\hline \multirow[t]{10}{*}{ ENC-SOUTH } & Algeria & 2005 & Roadmap , Negotiations pending for AP & No & No \\
\hline & Egypt & June 2004 & March 2007 & No & No \\
\hline & Israel & June 2000 & May 2005 & No & No \\
\hline & Jordan & May 2002 & January 2005 & Yes & No \\
\hline & Lebanon & April 2006 & January 2007 & No & No \\
\hline & Libya & Negotiations pending & No action plan yet & No & No \\
\hline & Morocco & March 2000 & July 2005 & No & No \\
\hline & Occupied Palestinian territories & July 1997 & May 2005 & No & No \\
\hline & Syria & Ratification pending & No action plan yet & No & No \\
\hline & Tunisia & March 1998 & July 2005 & No & No \\
\hline
\end{tabular}

Source: Wesselink and Boschma (2015). [1] PCA = Partnership and Cooperation Agreement.

[2] AA = Association Agreement. [3] CFSP = Common Foreign Security Policy statement. [4] FTA = Free trade agreement. 
Table 2. Regional rankings according to ISEPI values in 1995 and 2013

\begin{tabular}{|c|c|c|c|c|c|c|c|c|c|c|c|c|}
\hline & \multicolumn{3}{|c|}{ All Countries } & \multicolumn{3}{|c|}{ Developed } & \multicolumn{3}{|c|}{ EU } & \multicolumn{3}{|c|}{ ENC-EAST } \\
\hline & 2013 & 1995 & Change & 2013 & 1995 & Change & 2013 & 1995 & Change & 2013 & 1995 & Change \\
\hline ISEPI & 3.13 & 2.89 & 0.24 & 4.09 & 3.73 & 0.36 & 3.64 & 3.14 & 0.50 & 2.42 & 2.33 & 0.09 \\
\hline D1. Macroeconomic Environment & 1.66 & 1.45 & 0.21 & 2.18 & 2.04 & 0.14 & 1.80 & 1.45 & 0.35 & 1.46 & 0.94 & 0.52 \\
\hline D2. Cost \& Prices & 5.89 & 5.67 & 0.22 & 5.71 & 5.54 & 0.17 & 5.95 & 5.61 & 0.34 & 5.59 & 5.53 & 0.06 \\
\hline D3. Productivity and human capital & 3.02 & 2.83 & 0.19 & 3.81 & 3.75 & 0.06 & 4.13 & 3.71 & 0.42 & 2.38 & 2.11 & 0.27 \\
\hline D4. Technological and innovative capital & 2.43 & 2.14 & 0.29 & 4.17 & 3.85 & 0.32 & 3.17 & 2.60 & 0.57 & 1.35 & 1.32 & 0.03 \\
\hline D5. Market potential & 1.32 & 1.27 & 0.05 & 2.35 & 2.23 & 0.12 & 1.01 & 0.98 & 0.03 & 0.81 & 0.50 & 0.31 \\
\hline D6. Quality of life and labour market conditions & 4.28 & 3.66 & 0.62 & 5.42 & 3.68 & 1.74 & 5.07 & 3.66 & 1.41 & 3.42 & 3.80 & -0.38 \\
\hline \multirow[t]{3}{*}{ D7. Business-friendly environment } & 3.31 & 3.20 & 0.11 & 4.98 & 4.99 & -0.01 & 4.33 & 3.99 & 0.34 & 1.92 & 2.14 & -0.22 \\
\hline & \multicolumn{3}{|c|}{ Russia } & \multicolumn{3}{|c|}{ ENC-SOUTH } & \multicolumn{3}{|c|}{ Emerging } & \multicolumn{3}{|c|}{ Developing } \\
\hline & 2013 & 1995 & Change & 2013 & 1995 & Change & 2013 & 1995 & Change & 2013 & 1995 & Change \\
\hline ISEPI & 2.56 & 1.87 & 0.69 & 2.75 & 2.70 & 0.05 & 2.63 & 2.58 & 0.05 & 2.15 & 2.29 & -0.14 \\
\hline D1. Macroeconomic Environment & 1.61 & 1.10 & 0.51 & 1.35 & 1.30 & 0.05 & 1.45 & 1.44 & 0.01 & 1.43 & 1.35 & 0.08 \\
\hline D2. Cost \& Prices & 6.1 & 5.65 & 0.45 & 5.91 & 6.03 & -0.12 & 6.08 & 5.79 & 0.29 & 5.77 & 5.47 & 0.30 \\
\hline D3. Productivity and human capital & 3.07 & 3.43 & -0.36 & 2.53 & 2.07 & 0.46 & 1.9 & 1.92 & -0.02 & 1.25 & 1.66 & -0.41 \\
\hline D4. Technological and innovative capital & 2.54 & 1.19 & 1.35 & 1.62 & 1.52 & 0.10 & 1.59 & 1.36 & 0.23 & 1.04 & 1.33 & -0.29 \\
\hline D5. Market potential & 1.05 & 0.76 & 0.29 & 1.41 & 1.52 & -0.11 & 1.31 & 1.37 & -0.06 & 1.36 & 1.21 & 0.15 \\
\hline D6. Quality of life and labour market conditions & 2.37 & 0.45 & 1.92 & 3.71 & 3.75 & -0.04 & 3.73 & 3.70 & 0.03 & 2.77 & 3.74 & -0.97 \\
\hline D7. Business-friendly environment & 1.22 & 0.48 & 0.74 & 2.72 & 2.74 & -0.02 & 2.37 & 2.48 & -0.11 & 1.42 & 1.25 & 0.17 \\
\hline
\end{tabular}


Table 3. Country rankings according to ISEPI values in 1995 and 2013 (1/2)

\begin{tabular}{|c|c|c|c|c|c|c|c|c|c|c|c|}
\hline \multirow[b]{2}{*}{ Region } & \multirow[b]{2}{*}{ Country } & \multirow[b]{2}{*}{ ISO } & \multicolumn{3}{|c|}{2013} & \multicolumn{3}{|c|}{1995} & \multicolumn{3}{|c|}{ Change between 1995 and 2013} \\
\hline & & & ISEPI & $\begin{array}{c}\text { Global } \\
\text { Rank }\end{array}$ & $\begin{array}{c}\text { Region } \\
\text { Rank }\end{array}$ & ISEPI & $\begin{array}{c}\text { Global } \\
\text { Rank }\end{array}$ & $\begin{array}{c}\text { Region } \\
\text { Rank }\end{array}$ & ISEPI & $\begin{array}{c}\text { Global } \\
\text { Change }\end{array}$ & $\begin{array}{l}\text { Regional } \\
\text { Change }\end{array}$ \\
\hline \multirow{10}{*}{ 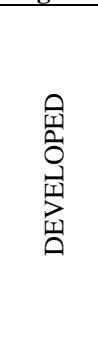 } & Singapore & SGP & 5.42 & 1 & 1 & 5.09 & 1 & 1 & 0.33 & 0 & 0 \\
\hline & Switzerland & CHE & 4.45 & 8 & 2 & 3.84 & 8 & 5 & 0.62 & 0 & 3 \\
\hline & United States of America & USA & 4.36 & 9 & 3 & 4.32 & 2 & 2 & 0.05 & -7 & -1 \\
\hline & Canada & CAN & 4.16 & 13 & 4 & 3.94 & 5 & 3 & 0.22 & -8 & -1 \\
\hline & Korea, Republic of & KOR & 4.14 & 14 & 5 & 3.55 & 17 & 7 & 0.59 & 3 & 2 \\
\hline & Japan & JPN & 4.03 & 16 & 6 & 3.82 & 10 & 6 & 0.21 & -6 & 0 \\
\hline & Australia & AUS & 3.94 & 18 & 7 & 3.93 & 6 & 4 & 0.01 & -12 & -3 \\
\hline & United Arab Emirates & ARE & 3.66 & 21 & 8 & 3.15 & 21 & 8 & 0.51 & 0 & 0 \\
\hline & Qatar & QAT & 3.49 & 25 & 9 & 2.92 & 26 & 9 & 0.57 & 1 & 0 \\
\hline & Saudi Arabia & SAU & 3.22 & 30 & 10 & 2.73 & 37 & 10 & 0.49 & 7 & 0 \\
\hline \multirow{27}{*}{ lit } & Luxembourg & LUX & 4.93 & 2 & 1 & 3.52 & 18 & 11 & 1.41 & 16 & 10 \\
\hline & Sweden & SWE & 4.62 & 3 & 2 & 4.20 & 3 & 1 & 0.41 & 0 & -1 \\
\hline & Finland & FIN & 4.56 & 4 & 3 & 4.19 & 4 & 2 & 0.37 & 0 & -1 \\
\hline & Denmark & DNK & 4.53 & 5 & 4 & 3.88 & 7 & 3 & 0.65 & 2 & -1 \\
\hline & Netherlands & NLD & 4.47 & 6 & 5 & 3.81 & 11 & 5 & 0.66 & 5 & 0 \\
\hline & Ireland & IRL & 4.47 & 7 & 6 & 3.83 & 9 & 4 & 0.64 & 2 & -2 \\
\hline & Belgium & BEL & 4.32 & 10 & 7 & 3.58 & 16 & 10 & 0.74 & 6 & 3 \\
\hline & Austria & AUT & 4.21 & 12 & 8 & 3.58 & 15 & 9 & 0.62 & 3 & 1 \\
\hline & Germany & DEU & 4.04 & 15 & 9 & 3.63 & 13 & 7 & 0.41 & -2 & -2 \\
\hline & United Kingdom & GBR & 3.95 & 17 & 10 & 3.59 & 14 & 8 & 0.37 & -3 & -2 \\
\hline & France & FRA & 3.93 & 19 & 11 & 3.68 & 12 & 6 & 0.25 & -7 & -5 \\
\hline & Spain & ESP & 3.34 & 27 & 16 & 3.06 & 23 & 13 & 0.28 & -4 & -3 \\
\hline & Portugal & PRT & 3.25 & 29 & 18 & 2.86 & 28 & 16 & 0.39 & -1 & -2 \\
\hline & Italy & ITA & 3.18 & 32 & 19 & 3.07 & 22 & 12 & 0.11 & -10 & -7 \\
\hline & Greece & GRC & 2.83 & 39 & 25 & 2.77 & 32 & 18 & 0.06 & -7 & -7 \\
\hline & Estonia & EST & 3.59 & 22 & 12 & 2.61 & 42 & 20 & 0.99 & 20 & 8 \\
\hline & Malta & MLT & 3.58 & 23 & 13 & 3.02 & 24 & 14 & 0.57 & 1 & 1 \\
\hline & Slovenia & SVN & 3.57 & 24 & 14 & 2.81 & 29 & 17 & 0.76 & 5 & 3 \\
\hline & Czech Republic & CZE & 3.38 & 26 & 15 & 2.76 & 33 & 19 & 0.62 & 7 & 4 \\
\hline & Lithuania & LTU & 3.32 & 28 & 17 & 2.52 & 49 & 23 & 0.80 & 21 & 6 \\
\hline & Poland & POL & 3.12 & 33 & 20 & 2.36 & 66 & 27 & 0.76 & 33 & 7 \\
\hline & Cyprus & CYP & 3.12 & 34 & 21 & 2.99 & 25 & 15 & 0.14 & -9 & -6 \\
\hline & Hungary & HUN & 3.08 & 35 & 22 & 2.50 & 50 & 24 & 0.57 & 15 & 2 \\
\hline & Latvia & LVA & 3.05 & 36 & 23 & 2.46 & 52 & 25 & 0.59 & 16 & 2 \\
\hline & Slovakia & SVK & 2.93 & 38 & 24 & 2.57 & 44 & 21 & 0.35 & 6 & -3 \\
\hline & Bulgaria & BGR & 2.48 & 56 & 26 & 2.55 & 46 & 22 & -0.07 & -10 & -4 \\
\hline & Romania & ROU & 2.38 & 62 & 27 & 2.44 & 54 & 26 & -0.07 & -8 & -1 \\
\hline
\end{tabular}


Table 3. Country rankings according to ISEPI values in 1995 and 2013 (2/2)

\begin{tabular}{|c|c|c|c|c|c|c|c|c|c|c|c|}
\hline \multirow[b]{2}{*}{ Region } & \multirow[b]{2}{*}{ Country } & \multirow[b]{2}{*}{ ISO } & \multicolumn{3}{|c|}{2013} & \multicolumn{3}{|c|}{1995} & \multicolumn{3}{|c|}{ Change between 1995 and 2013} \\
\hline & & & ISEPI & Global Rank & Region Rank & ISEPI & Global Rank & Region Rank & ISEPI & Global Change & Regional Change \\
\hline \multirow{6}{*}{ 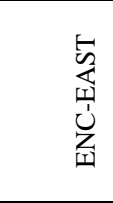 } & Georgia & GEO & 2.56 & 52 & 1 & 2.36 & 65 & 3 & 0.20 & 13 & 2 \\
\hline & Azerbaijan & AZE & 2.55 & 54 & 2 & 2.33 & 68 & 4 & 0.23 & 14 & 2 \\
\hline & Armenia & ARM & 2.50 & 55 & 3 & 2.21 & 74 & 6 & 0.29 & 19 & 3 \\
\hline & Moldova & MDA & 2.38 & 63 & 4 & 2.41 & 59 & 1 & -0.04 & -4 & -3 \\
\hline & Belarus & BLR & 2.27 & 66 & 5 & 2.39 & 62 & 2 & -0.13 & -4 & -3 \\
\hline & Ukraine & UKR & 2.25 & 68 & 6 & 2.30 & 70 & 5 & -0.05 & 2 & -1 \\
\hline RUSSIA & Russian Federation & RUS & 2.56 & 50 & 1 & 1.87 & 75 & 1 & 0.70 & 25 & 0 \\
\hline \multirow{10}{*}{ 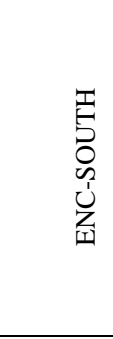 } & Israel & ISR & 4.31 & 11 & 1 & 3.49 & 19 & 1 & 0.82 & 8 & 0 \\
\hline & Jordan & JOR & 2.80 & 40 & 2 & 2.73 & 36 & 4 & 0.06 & -4 & 2 \\
\hline & Palestine & PSE & 2.76 & 41 & 3 & 2.73 & 35 & 3 & 0.03 & -6 & 0 \\
\hline & Lebanon & LBN & 2.70 & 44 & 4 & 2.79 & 31 & 2 & -0.09 & -13 & -2 \\
\hline & Libya & LBY & 2.68 & 46 & 5 & 2.61 & 41 & 6 & 0.07 & -5 & 1 \\
\hline & Tunisia & TUN & 2.67 & 47 & 6 & 2.59 & 43 & 7 & 0.08 & -4 & 1 \\
\hline & Morocco & MAR & 2.56 & 51 & 7 & 2.40 & 61 & 9 & 0.16 & 10 & 2 \\
\hline & Egypt & EGY & 2.31 & 64 & 8 & 2.56 & 45 & 8 & -0.26 & -19 & 0 \\
\hline & Algeria & DZA & 2.26 & 67 & 9 & 2.35 & 67 & 10 & -0.08 & 0 & 1 \\
\hline & Syrian Arab Republic (Syria) & SYR & 2.15 & 70 & 10 & 2.68 & 38 & 5 & -0.54 & -32 & -5 \\
\hline \multirow{14}{*}{$\begin{array}{l}0 \\
\sum_{0} \\
\stackrel{2}{x} \\
\sum_{i=1}\end{array}$} & Malaysia & MYS & 3.70 & 20 & 1 & 3.20 & 20 & 1 & 0.50 & 0 & 0 \\
\hline & Chile & CHL & 3.19 & 31 & 2 & 2.91 & 27 & 2 & 0.28 & -4 & 0 \\
\hline & Thailand & THA & 3.04 & 37 & 3 & 2.81 & 30 & 3 & 0.23 & -7 & 0 \\
\hline & Turkey & TUR & 2.73 & 42 & 4 & 2.42 & 57 & 12 & 0.31 & 15 & 8 \\
\hline & Mexico & MEX & 2.73 & 43 & 5 & 2.46 & 51 & 8 & 0.26 & 8 & 3 \\
\hline & China & CHN & 2.65 & 48 & 6 & 2.43 & 56 & 11 & 0.23 & 8 & 5 \\
\hline & Viet Nam & VNM & 2.57 & 49 & 7 & 2.55 & 47 & 6 & 0.02 & -2 & -1 \\
\hline & Philippines & PHL & 2.56 & 53 & 8 & 2.75 & 34 & 4 & -0.19 & -19 & -4 \\
\hline & Argentina & ARG & 2.45 & 57 & 9 & 2.68 & 39 & 5 & -0.23 & -18 & -4 \\
\hline & Brazil & BRA & 2.45 & 58 & 10 & 2.43 & 55 & 10 & 0.02 & -3 & 0 \\
\hline & Indonesia & IDN & 2.43 & 60 & 11 & 2.41 & 60 & 13 & 0.02 & 0 & 2 \\
\hline & Peru & PER & 2.43 & 61 & 12 & 2.53 & 48 & 7 & -0.10 & -13 & -5 \\
\hline & South Africa & ZAF & 2.29 & 65 & 13 & 2.29 & 71 & 14 & 0.00 & 6 & 1 \\
\hline & India & IND & 2.04 & 72 & 14 & 2.46 & 53 & 9 & -0.41 & -19 & -5 \\
\hline \multirow{8}{*}{ 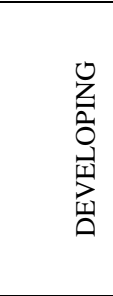 } & Kazakhstan & KAZ & 2.69 & 45 & 1 & 2.37 & 64 & 4 & 0.33 & 19 & 3 \\
\hline & Colombia & COL & 2.44 & 59 & 2 & 2.37 & 63 & 3 & 0.07 & 4 & 1 \\
\hline & Senegal & SEN & 2.16 & 69 & 3 & 2.42 & 58 & 2 & -0.26 & -11 & -1 \\
\hline & Iran, Islamic Republic of & IRN & 2.14 & 71 & 4 & 2.62 & 40 & 1 & -0.48 & -31 & -3 \\
\hline & Kenya & KEN & 2.00 & 73 & 5 & 2.31 & 69 & 5 & -0.31 & -4 & 0 \\
\hline & Tanzania, United Republic of & TZA & 1.95 & 74 & 6 & 2.22 & 73 & 7 & -0.27 & -1 & 1 \\
\hline & Angola & AGO & 1.94 & 75 & 7 & 1.71 & 76 & 8 & 0.22 & 1 & 1 \\
\hline & Nigeria & NGA & 1.88 & 76 & 8 & 2.28 & 72 & 6 & -0.41 & -4 & -2 \\
\hline
\end{tabular}


Table 4. ENP Countries Conditional b-Convergence. ISEPI 1995-2013.

\begin{tabular}{|c|c|c|c|c|c|c|c|c|}
\hline $1995-2013$ & ISEPI & D1 & D2 & D3 & $\mathrm{D} 4$ & D5 & D6 & D7 \\
\hline Initial value & $\begin{array}{c}-0.265^{* * *} \\
{[0.017]}\end{array}$ & $\begin{array}{c}-0.252^{* * *} \\
{[0.021]}\end{array}$ & $\begin{array}{c}-0.409^{* * *} \\
{[0.022]}\end{array}$ & $\begin{array}{c}-0.172^{* * *} \\
{[0.016]}\end{array}$ & $\begin{array}{l}-0.141^{* * *} \\
{[0.014]}\end{array}$ & $\begin{array}{c}-0.312^{* * *} \\
{[0.015]}\end{array}$ & $\begin{array}{c}-0.276^{* * *} \\
{[0.016]}\end{array}$ & $\begin{array}{c}-0.290^{* * *} \\
{[0.019]}\end{array}$ \\
\hline ENP_plan & $\begin{array}{c}0.002 \\
{[0.005]}\end{array}$ & $\begin{array}{c}-0.068^{* * *} \\
{[0.023]}\end{array}$ & $\begin{array}{l}-0.008 \\
{[0.011]}\end{array}$ & $\begin{array}{c}-0.012 \\
{[0.016]}\end{array}$ & $\begin{array}{l}0.059^{* * * *} \\
{[0.015]}\end{array}$ & $\begin{array}{l}0.031^{* *} \\
{[0.012]}\end{array}$ & $\begin{array}{c}0.010 \\
{[0.014]}\end{array}$ & $\begin{array}{c}-0.011 \\
{[0.019]}\end{array}$ \\
\hline ENP_contract & $\begin{array}{c}-0.002 \\
{[0.006]}\end{array}$ & $\begin{array}{l}0.105^{* * *} \\
{[0.027]}\end{array}$ & $\begin{array}{c}-0.003 \\
{[0.013]}\end{array}$ & $\begin{array}{c}-0.019 \\
{[0.020]}\end{array}$ & $\begin{array}{l}-0.017 \\
{[0.018]}\end{array}$ & $\begin{array}{c}-0.041^{* * *} \\
{[0.015]}\end{array}$ & $\begin{array}{c}-0.037^{* *} \\
{[0.017]}\end{array}$ & $\begin{array}{c}0.040^{*} \\
{[0.022]}\end{array}$ \\
\hline Constant & $\begin{array}{c}-0.265^{* * *} \\
{[0.017]}\end{array}$ & $\begin{array}{l}0.084^{* * * *} \\
{[0.008]}\end{array}$ & $\begin{array}{l}0.721^{* * * *} \\
{[0.038]}\end{array}$ & $\begin{array}{l}0.165^{* * *} \\
{[0.016]}\end{array}$ & $\begin{array}{l}0.091^{* * *} \\
{[0.009]}\end{array}$ & $\begin{array}{l}0.057^{* * * *} \\
{[0.003]}\end{array}$ & $\begin{array}{l}0.387^{* * * *} \\
{[0.023]}\end{array}$ & $\begin{array}{l}0.285^{* * * *} \\
{[0.019]}\end{array}$ \\
\hline $\begin{array}{l}\text { Country fixed effects } \\
\text { Year fixed effects }\end{array}$ & $\begin{array}{l}\text { YES } \\
\text { NO }\end{array}$ & $\begin{array}{l}\text { YES } \\
\text { NO }\end{array}$ & $\begin{array}{l}\text { YES } \\
\text { NO }\end{array}$ & $\begin{array}{l}\text { YES } \\
\text { NO }\end{array}$ & $\begin{array}{l}\text { YES } \\
\text { NO }\end{array}$ & $\begin{array}{l}\text { YES } \\
\text { NO }\end{array}$ & $\begin{array}{l}\text { YES } \\
\text { NO }\end{array}$ & $\begin{array}{l}\text { YES } \\
\text { NO }\end{array}$ \\
\hline $\begin{array}{l}\text { Observations } \\
\text { R-squared } \\
\text { Number of countries }\end{array}$ & $\begin{array}{c}1366 \\
0.159 \\
76 \\
\end{array}$ & $\begin{array}{c}1366 \\
0.106 \\
76 \\
\end{array}$ & $\begin{array}{c}1366 \\
0.216 \\
76 \\
\end{array}$ & $\begin{array}{c}1366 \\
0.084 \\
76 \\
\end{array}$ & $\begin{array}{c}1367 \\
0.082 \\
76 \\
\end{array}$ & $\begin{array}{c}1367 \\
0.263 \\
76 \\
\end{array}$ & $\begin{array}{c}1366 \\
0.180 \\
76 \\
\end{array}$ & $\begin{array}{c}1366 \\
0.158 \\
76 \\
\end{array}$ \\
\hline $1995-2013$ & ISEPI & D1 & D2 & D3 & D4 & D5 & $\bar{D} 6$ & D7 \\
\hline Initial value & $\begin{array}{l}-0.290^{* * *} \\
{[0.018]}\end{array}$ & $\begin{array}{c}-0.246^{* * *} \\
{[0.021]}\end{array}$ & $\begin{array}{c}-0.407^{* * *} \\
{[0.022]}\end{array}$ & $\begin{array}{l}-0.171^{* * *} \\
{[0.016]}\end{array}$ & $\begin{array}{l}-0.139^{* * *} \\
{[0.014]}\end{array}$ & $\begin{array}{c}-0.320^{* * *} \\
{[0.015]}\end{array}$ & $\begin{array}{c}-0.279^{* * *} \\
{[0.017]}\end{array}$ & $\begin{array}{l}-0.290^{* * *} \\
{[0.019]}\end{array}$ \\
\hline ENP_plan & $\begin{array}{l}-0.006 \\
{[0.005]}\end{array}$ & $\begin{array}{c}-0.063^{* * * *} \\
{[0.024]}\end{array}$ & $\begin{array}{c}-0.011 \\
{[0.011]}\end{array}$ & $\begin{array}{l}-0.017 \\
{[0.017]}\end{array}$ & $\begin{array}{l}0.059^{* * * *} \\
{[0.016]}\end{array}$ & $\begin{array}{l}0.029^{* *} \\
{[0.013]}\end{array}$ & $\begin{array}{c}-0.016 \\
{[0.014]}\end{array}$ & $\begin{array}{l}-0.010 \\
{[0.020]}\end{array}$ \\
\hline ENP_contract & $\begin{array}{c}-0.005 \\
{[0.006]}\end{array}$ & $\begin{array}{l}0.100^{* * * *} \\
{[0.028]}\end{array}$ & $\begin{array}{c}-0.002 \\
{[0.013]}\end{array}$ & $\begin{array}{c}-0.019 \\
{[0.020]}\end{array}$ & $\begin{array}{c}-0.023 \\
{[0.019]}\end{array}$ & $\begin{array}{c}-0.051^{* * *} \\
{[0.015]}\end{array}$ & $\begin{array}{c}-0.023 \\
{[0.017]}\end{array}$ & $\begin{array}{c}0.026 \\
{[0.023]}\end{array}$ \\
\hline Constant & $\begin{array}{l}0.318^{* * *} \\
{[0.019]}\end{array}$ & $\begin{array}{l}0.088^{* * *} \\
{[0.019]}\end{array}$ & $\begin{array}{l}0.727^{* * *} \\
{[0.039]}\end{array}$ & $\begin{array}{c}0.166^{* * *} \\
{[0.020]}\end{array}$ & $\begin{array}{l}0.071^{* * * *} \\
{[0.014]}\end{array}$ & $\begin{array}{l}0.048^{* * *} \\
{[0.009]}\end{array}$ & $\begin{array}{l}0.409^{* * *} \\
{[0.025]}\end{array}$ & $\begin{array}{l}0.301^{* * *} \\
{[0.023]}\end{array}$ \\
\hline $\begin{array}{l}\text { Country fixed effects } \\
\text { Year fixed effects }\end{array}$ & $\begin{array}{l}\text { YES } \\
\text { YES }\end{array}$ & $\begin{array}{l}\text { YES } \\
\text { YES }\end{array}$ & $\begin{array}{l}\text { YES } \\
\text { YES }\end{array}$ & $\begin{array}{l}\text { YES } \\
\text { YES }\end{array}$ & $\begin{array}{l}\text { YES } \\
\text { YES }\end{array}$ & $\begin{array}{l}\text { YES } \\
\text { YES }\end{array}$ & $\begin{array}{l}\text { YES } \\
\text { YES }\end{array}$ & $\begin{array}{l}\text { YES } \\
\text { YES }\end{array}$ \\
\hline Observations & 1368 & 1366 & 1366 & 1366 & 1367 & 1367 & 1366 & 1366 \\
\hline R-squared & 0.186 & 0.126 & 0.233 & 0.108 & 0.104 & 0.286 & 0.232 & 0.175 \\
\hline Number of countries & 76 & 76 & 76 & 76 & 76 & 76 & 76 & 76 \\
\hline
\end{tabular}

Standard errors in brackets. ${ }^{*} p<0.10,{ }^{* *} p<0.05,{ }^{* * *} p<0.01$ 


\section{ANNEX}

Table A.1. Countries included in the ISEPI Index.

\begin{tabular}{|c|c|c|c|c|c|c|c|}
\hline & Country & ISO & Group & & Country & ISO & Group \\
\hline 1 & Angola & AGO & DEVELOPING & 39 & Kazakhstan & KAZ & DEVELOPING \\
\hline 2 & United Arab Emirates & ARE & DEVELOPED & 40 & Kenya & KEN & DEVELOPING \\
\hline 3 & Argentina & ARG & EMERGING & 41 & Korea, Republic of & KOR & DEVELOPED \\
\hline 4 & Armenia & ARM & ENC-EAST & 42 & Lebanon & LBN & ENC-SOUTH \\
\hline 5 & Australia & AUS & DEVELOPED & 43 & Libya & LBY & ENC-SOUTH \\
\hline 6 & Austria & AUT & EU & 44 & Lithuania & LTU & EU \\
\hline 7 & Azerbaijan & AZE & ENC-EAST & 45 & Luxembourg & LUX & EU \\
\hline 8 & Belgium & BEL & EU & 46 & Latvia & LVA & EU \\
\hline 9 & Bulgaria & BGR & EU & 47 & Morocco & MAR & ENC-SOUTH \\
\hline 10 & Belarus & BLR & ENC-EAST & 48 & Moldova & MDA & ENC-EAST \\
\hline 11 & Brazil & BRA & EMERGING & 49 & Mexico & MEX & EMERGING \\
\hline 12 & Canada & CAN & DEVELOPED & 50 & Malta & MLT & EU \\
\hline 13 & Switzerland & CHE & DEVELOPED & 51 & Malaysia & MYS & EMERGING \\
\hline 14 & Chile & CHL & EMERGING & 52 & Nigeria & NGA & DEVELOPING \\
\hline 15 & China & $\mathrm{CHN}$ & EMERGING & 53 & Netherlands & NLD & EU \\
\hline 16 & Colombia & COL & DEVELOPING & 54 & Peru & PER & EMERGING \\
\hline 17 & Cyprus & CYP & EU & 55 & Philippines & PHL & EMERGING \\
\hline 18 & Czech Republic & CZE & EU & 56 & Poland & POL & EU \\
\hline 19 & Germany & DEU & EU & 57 & Portugal & PRT & EU \\
\hline 20 & Denmark & DNK & EU & 58 & Palestine & PSE & ENC-SOUTH \\
\hline 21 & Algeria & DZA & ENC-SOUTH & 59 & Qatar & QAT & DEVELOPED \\
\hline 22 & Egypt & EGY & ENC-SOUTH & 60 & Romania & ROU & $\mathrm{EU}$ \\
\hline 23 & Spain & ESP & EU & 61 & Russian Federation & RUS & RUSSIA \\
\hline 24 & Estonia & EST & EU & 62 & Saudi Arabia & SAU & DEVELOPED \\
\hline 25 & Finland & FIN & EU & 63 & Senegal & SEN & DEVELOPING \\
\hline 26 & France & FRA & EU & 64 & Singapore & SGP & DEVELOPED \\
\hline 27 & United Kingdom & GBR & $\mathrm{EU}$ & 65 & Slovakia & SVK & EU \\
\hline 28 & Georgia & GEO & ENC-EAST & 66 & Slovenia & SVN & EU \\
\hline 29 & Greece & GRC & EU & 67 & Sweden & SWE & EU \\
\hline 30 & Hungary & HUN & EU & 68 & Syrian Arab Republic (Syria) & SYR & ENC-SOUTH \\
\hline 31 & Indonesia & IDN & EMERGING & 69 & Thailand & THA & ENC-SOUTH \\
\hline 32 & India & IND & EMERGING & 70 & Tunisia & TUN & ENC-SOUTH \\
\hline 33 & Ireland & IRL & EU & 71 & Turkey & TUR & EMERGING \\
\hline 34 & Iran, Islamic Republic of & IRN & DEVELOPING & 72 & Tanzania, United Republic of & TZA & DEVELOPING \\
\hline 35 & Israel & ISR & ENC-SOUTH & 73 & Ukraine & UKR & ENC-EAST \\
\hline 36 & Italy & ITA & $\mathrm{EU}$ & 74 & United States of America & USA & DEVELOPED \\
\hline 37 & Jordan & JOR & ENC-SOUTH & 75 & Viet Nam & VNM & EMERGING \\
\hline 38 & Japan & JPN & DEVELOPED & 76 & South Africa & ZAF & EMERGING \\
\hline
\end{tabular}


Table A.2. Data sources and description of variables (1/4)

\begin{tabular}{llll}
\hline D1. Macroeconomic environment & $(+)$ & Source & Description \\
\hline v1 GDP growth rate & $(+) \quad$ WDI & $\begin{array}{l}\text { Annual percentage growth rate of GDP at market prices based on constant } \\
\text { local currency. Aggregates are based on constant 2005 U.S. dollars. GDP is } \\
\text { the sum of gross value added by all resident producers in the economy plus } \\
\text { any product taxes and minus any subsidies not included in the value of the } \\
\text { products. It is calculated without making deductions for depreciation of } \\
\text { fabricated assets or for depletion and degradation of natural resources }\end{array}$ \\
\hline v2 Activity rate & $(+) \quad$ WDI & $\begin{array}{l}\text { Labor force participation rate is the proportion of the population ages 15 and } \\
\text { older that is economically active: all people who supply labor for the } \\
\text { production of goods and services during a specified period. }\end{array}$ \\
\hline
\end{tabular}

v3 Unemployment rate

(-) WDI available for and seeking employment. Definitions of labor force and

$1995-2012$

unemployment differ by country.

Cash surplus or deficit is revenue (including grants) minus expense. minus net acquisition of nonfinancial assets. In the 1986 GFS manual nonfinancial

v4 Public surplus/deficit as percentage of GDP

(+) WDI assets were included under revenue and expenditure in gross terms. This cash surplus or deficit is closest to the earlier overall budget balance (still missing is lending minus repayments. which are now a financing item under net acquisition of financial assets).

Debt is the entire stock of direct government fixed-term contractual

obligations to others outstanding on a particular date. It includes domestic

and foreign liabilities such as currency and money deposits. securities other

v5 Public debt as percentage of GDP

$(-) \quad$ WDI

than shares. and loans. It is the gross amount of government liabilities

reduced by the amount of equity and financial derivatives held by the

government. Because debt is a stock rather than a flow, it is measured as of a

given date. usually the last day of the fiscal year.

\begin{tabular}{llll}
\hline v6 & Current account surplus/deficit as percentage of GDP & $(+)$ & WDI \\
\hline v7 & Inflow Foreign Direct Investment as percentage of GDP & $(+)$ & UNCTAD
\end{tabular}

Current account balance is the sum of net exports of goods and services. net

primary income. and net secondary income.

Inflow: FDI stock is the value of the share of their capital and reserves

v7 Inflow Foreign Direct Investment as percentage of GDP $\quad(+)$ UNCTAD (including retained profits) attributable to the parent enterprise. plus the net indebtedness of affiliates to the parent enterprises.

Outflow: FDI stock is the value of the share of their capital and reserves

v8 Outflow Foreign Direct Investment as percentage of GDP

(+) UNCTAD indebtedness of affiliates to the parent enterprises.

\begin{tabular}{lllll}
\hline v9 & Trade openness (exports+imports)/2·GDP & $(+)$ & WDI & $\begin{array}{l}\text { Trade is the sum of exports and imports of goods and services measured as a } \\
\text { share of gross domestic product. }\end{array}$ \\
\hline v10 & Services exports as percentage of GDP & $(+)$ & WDI & $\begin{array}{l}\text { Trade in services is the sum of service exports and imports divided by the } \\
\text { value of GDP. all in current U.S. dollars. }\end{array}$ \\
\hline v11 & Stock market capitalization as a percentage of GDP & $(+)$ & IMD & $\begin{array}{l}\text { Stock market capitalization as a percentage of GDP. Standard \& Poor’s. } \\
\text { Global Stock Markets Factbook 2012. }\end{array}$ \\
\hline v12 & Savings rate & $(+)$ & WDI & $\begin{array}{l}\text { Gross savings are calculated as gross national income less total } \\
\text { consumption. plus net transfers. }\end{array}$ \\
\hline
\end{tabular}

D2. Costs and prices

(-) Source

Description

Period

v13 Consumer price inflation

$(-) \quad$ WDI

Inflation as measured by the consumer price index reflects the annua

percentage change in the cost to the average consumer of acquiring a basket of goods and services that may be fixed or changed at specified intervals.

$1995-2011$

v14 Labour unit costs growth rates such as yearly. The Laspeyres formula is generally used.

\begin{tabular}{llcll}
\hline v14 & Labour unit costs growth rates & $(-)$ & IMD & $\begin{array}{l}\text { Labour unit costs growth rates. OECD unit labor costs database April 2011. } \\
\text { National sources. }\end{array}$ \\
\hline v15 & Hourly wage in manufacturing & $(-)$ & IMD & $\begin{array}{l}\text { Average number of working hours per year. UBS Prices and Earnings 2012. } \\
\text { National sources }\end{array}$ \\
\hline v16 & Cost of life (New York=100) & $(-)$ & IMD & $\begin{array}{l}\text { 1995-2013 } \\
\text { (New York City = 100). MERCER Cost of Living survey. March 2013. } \\
\text { www.mercer.com }\end{array}$ \\
\hline v17 Real effective exchange rate (ULC adjusted) & $(-)$ & WDI & $\begin{array}{l}\text { Real effective exchange rate is the nominal effective exchange rate (a } \\
\text { measure of the value of a currency against a weighted average of several } \\
\text { foreign currencies) divided by a price deflator or index of costs. }\end{array}$ \\
\hline
\end{tabular}


Table A.2. Data sources and description of variables (2/4)

\begin{tabular}{|c|c|c|}
\hline D3. Productivity and human capital & $(+)$ & Source \\
\hline v18 Labour productivity (GDP per worker) & $(+)$ & TCB \\
\hline
\end{tabular}

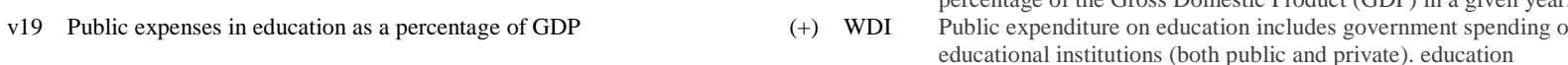

expenditure (current and capital) on education expressed as a

percentage of the Gross Domestic Product (GDP) in a given year.

$1995-2012$

administration, and transfers/subsidies for private entities

(students/households and other privates entities).

Gross enrolment ratio. Secondary. All programmes. Total is the total enrollment in secondary education. regardless of age. expressed as

percentage of the population of official secondary education age.

GER can exceed $100 \%$ due to the inclusion of over-aged and under-
aged students because of early or late school entrance and grade

1995-2012

v20 Share of population between 25 and 34 years old with secondary studies

(+) WDI repetition.

Gross enrolment ratio. Tertiary (ISCED 5 and 6). Total is the total

v21 Share of population between 25 and 34 years old with tertiary studies

(+) WDI

enrollment in tertiary education (ISCED 5 and 6). regardless of age.

expressed as a percentage of the total population of the five-year age

$1995-2012$ group following on from secondary school leaving.

Researchers in R\&D are professionals engaged in the conception or

v22 Researchers in firms /1000 inhabitants

(+) WDI

and in the management of the projects concerned. Postgraduate PhD

1995-2012 students (ISCED97 level 6) engaged in R\&D are included.

\begin{tabular}{lllll}
\hline v23 & Qualified workforce available & $(+)$ & IMD & $\begin{array}{l}\text { Skilled labor is readily available. IMD WCY Executive Opinion } \\
\text { Survey based on an index from } 0 \text { to 10. }\end{array}$ \\
\hline v24 Entrepreneurship & $(+)$ & IMD & $\begin{array}{l}\text { Entrepreneurship of managers is widespread in business. IMD WCY } \\
\text { Executive Opinion Survey based on an index from } 0 \text { to } 10 .\end{array}$ \\
\hline
\end{tabular}

\section{D.4. Technological and innovative capacity}

(+) Source Description

Period

v25 Share of high technology exports on total exports

(+) WDI

High-technology exports are products with high R\&D intensity. such

as in aerospace. computers. pharmaceuticals. scientific instruments. and electrical machinery.

$\mathrm{R}+\mathrm{D}$ private expenses as a percentage of GDP. OECD Main Science

and Technology Indicators 2/2012.UNESCO

http://stats.uis.unesco.org.National sources.

Patent applications are worldwide patent applications filed through

the Patent Cooperation Treaty procedure or with a national patent

office for exclusive rights for an invention--a product or process that

provides a new way of doing something or offers a new technical

solution to a problem. A patent provides protection for the invention

to the owner of the patent for a limited period. generally 20 years.

Knowledge transfer is highly developed between companies and

v28 Transfer knowledge from university to firms

(+) IMD universities. IM
from 0 to 10 .

v29 Internet users / 1000 inhabitants

(+) WDI

Internet use

v30 Mobile phone users / 1000 inhabitants

(+) WDI mobile telephone service using cellular technology. which provide prepaid subscriptions are included.

v31 Computers / 1000 inhabitants

$\begin{array}{ll}\text { (+) IMD } & \begin{array}{l}\text { Number of computers per } 1000 \text { people. Computer Industry Almanac } \\ \text { Inc. April 2012. http://www.c-i-a.com. National sources. }\end{array}\end{array}$

1995-2012

1995-2012

$1995-2012$

$1995-2013$

1995-2012

$1997-2012$

(+) IMD Inc. April 2012. http://www.c-i-a.com. National sources.

$1995-2013$ 
Table A.2. Data sources and description of variables (3/4)

\begin{tabular}{|c|c|c|c|c|}
\hline D5. Market potential & $(+)$ & Source & Description & Period \\
\hline v32 Population & $(+)$ & WDI & Population. total refers to the total population. & 1995-2012 \\
\hline
\end{tabular}

v33 Share of population older than 65 years old on total population $\quad(-) \quad$ WDI $\quad \begin{aligned} & \text { Population is based on the de facto definition of population. which counts all } \\ & \text { residents regardless of legal status or citizenship--except for refugees not }\end{aligned}$

permanently settled in the country of asylum. who are generally considered part of the population of the country of origin.

\begin{tabular}{|c|c|c|c|c|c|}
\hline v34 & Population growth rate & $(+)$ & WDI & $\begin{array}{l}\text { Population growth (annual \%) is the exponential rate of growth of midyear } \\
\text { population from year t-1 to t. expressed as a percentage. }\end{array}$ & $1995-2012$ \\
\hline v35 & GDP (PPP) per capita & $(+)$ & WDI & $\begin{array}{l}\text { GDP per capita based on purchasing power parity (PPP). PPP GDP is gross } \\
\text { domestic product converted to international dollars using purchasing power } \\
\text { parity rates. An international dollar has the same purchasing power over } \\
\text { GDP as the U.S. dollar has in the United States. GDP at purchaser's prices is } \\
\text { the sum of gross value added by all resident producers in the economy plus } \\
\text { any product taxes and minus any subsidies not included in the value of the } \\
\text { products. It is calculated without making deductions for depreciation of } \\
\text { fabricated assets or for depletion and degradation of natural resources. Data } \\
\text { are in constant } 2005 \text { international dollars. }\end{array}$ & $1995-2012$ \\
\hline v36 & Population density (Inhabitants/km2) & $(+)$ & WDI & $\begin{array}{l}\text { Population density is midyear population divided by land area in square } \\
\text { kilometers. Population is based on the de facto definition of population. } \\
\text { which counts all residents regardless of legal status or citizenship--except for } \\
\text { refugees not permanently settled in the country of asylum. who are generally } \\
\text { considered part of the population of their country of origin. Land area is a } \\
\text { country's total area. excluding area under inland water bodies. national } \\
\text { claims to continental shelf. and exclusive economic zones. In most cases the } \\
\text { definition of inland water bodies includes major rivers and lakes. }\end{array}$ & $1995-2012$ \\
\hline v37 & Share of urban population on total population & $(+)$ & WDI & $\begin{array}{l}\text { Urban population refers to people living in urban areas as defined by } \\
\text { national statistical offices. It is calculated using World Bank population } \\
\text { estimates and urban ratios from the United Nations World Urbanization } \\
\text { Prospects. }\end{array}$ & $1995-2012$ \\
\hline
\end{tabular}

\begin{tabular}{lllll}
\hline D6. Quality of life and labour market conditions & $(+)$ & Source & Description \\
\hline v38 Life expectancy at birth & $(+)$ & WDI & $\begin{array}{l}\text { Life expectancy at birth indicates the number of years a newborn infant } \\
\text { would live if prevailing patterns of mortality at the time of its birth were to } \\
\text { stay the same throughout its life. }\end{array}$ \\
\hline v39 & Quality of life & $(+)$ & IMD & $\begin{array}{l}\text { Quality of life. IMD WCY Executive Opinion Survey based on an index } \\
\text { from 0 to 10. }\end{array}$ \\
\hline v40 & Personal security and private property protection & $(+)$ & IMD & $\begin{array}{l}\text { Personal security and private property rights are adequately protected. IMD } \\
\text { WCY Executive Opinion Survey based on an index from 0 to 10. }\end{array}$ \\
\hline v41 & Health expenses per capita & $(+)$ & WDI & $\begin{array}{l}\text { 1995-2013 } \\
\text { as a ratio of total population. It covers the provision of health services } \\
\text { emergency aid designated for health but does not include provision of water } \\
\text { and sanitation. Data are in international dollars converted using 2005 } \\
\text { purchasing power parity (PPP) rates. }\end{array}$ \\
\hline v42 & Workers motivation & $(+)$ & IMD & $\begin{array}{l}\text { Worker motivation in companies is high. IMD WCY Executive Opinion } \\
\text { Survey based on an index from 0 to 10. }\end{array}$ \\
\hline v43 & Hours of work & $(-)$ & IMD & $\begin{array}{l}\text { Average number of working hours per year. UBS Prices and Earnings 2012. } \\
\text { National sources. }\end{array}$ \\
\hline
\end{tabular}


Table A.2. Data sources and description of variables (4/4)

\begin{tabular}{lll}
\hline D7. Business-friendly environment & $(+)$ Source & Description \\
\hline v44 Global quality of infrastructures & $(+)$ WEF & $\begin{array}{l}\text { How would you assess general infrastructure }(\text { e.g.. transport. telephony. } \\
\text { and energy) in your country? }[1=\text { extremely underdeveloped; } 7=\end{array}$
\end{tabular}

v44 Global quality of infrastructures

(+) WEF and energy) in your country? [1 = extremely underdeveloped; 7 =

extensive and efficient by international standards). World Economic

2006-2012 Forum. Executive Opinion Survey. of production. (Number)

Export: All documents required per shipment to export goods are recorded. It is assumed that the contract has already been agreed upon and signed by both parties. Documents required for clearance by government ministries. customs authorities. port and container terminal authorities. health and technical control agencies and banks are taken into account. Since payment is by letter of credit. all documents required by banks for the issuance or securing of a letter of credit are also taken into account. Documents that are renewed annually and that do not require renewal per shipment (for example. an annual tax clearance certificate) are not included. (Number). Import: All documents required per shipment to import goods are recorded. It is assumed that the contract has already been agreed upon and signed by both parties. Documents required for clearance by government ministries. customs authorities. port and container terminal authorities. health and technical control agencies and banks are taken into account. Since payment is by letter of credit. all documents required by banks for the issuance or securing of a letter of credit are also taken into account. Documents that are renewed annually and that do not require renewal per shipment (for example. an annual tax clearance certificate) are not included. (Number).

Export: Cost measures the fees levied on a 20-foot container in U.S dollars. All the fees associated with completing the procedures to export or import the goods are included. These include costs for documents. administrative fees for customs clearance and technical control. customs broker fees. terminal handling charges and inland transport. The cost measure does not include tariffs or trade taxes. Only official costs are recorded. Several assumptions are made for the business surveyed: Has 60 or more employees; Is located in the country's most populous city; Is a private. limited liability company. It does not operate within an export processing zone or an industrial estate with special export or import privileges; Is domestically owned with no foreign ownership; Exports more than 10\% of its sales. Assumptions about the traded goods: The traded product travels in a dry-cargo. 20foot. full container load. The product: Is not hazardous nor does it include military items; Does not require refrigeration or any other special environment; Does not require any special phytosanitary or environmental safety standards other than accepted international standards. (Number). Import: Cost measures the fees levied on a 20foot container in U.S. dollars. All the fees associated with completing the procedures to export or import the goods are included. These include costs for documents. administrative fees for customs clearance and technical control. customs broker fees. terminal handling charges and inland transport. The cost measure does not include tariffs or trade taxes. Only official costs are recorded. (Number).

Transparency. accountability. and corruption in the public sector assess the extent to which the executive can be held accountable for its use of funds and for the results of its actions by the electorate and by the legislature and judiciary. and the extent to which public employees 
Table A.3. ISEPI Global Indicator and Dimensions. 1995-2013 (1/3)

\begin{tabular}{|c|c|c|c|c|c|c|c|c|c|c|}
\hline \multirow[b]{2}{*}{ Country } & \multirow[b]{2}{*}{ ISO } & \multicolumn{3}{|c|}{ ISEPI } & \multicolumn{3}{|c|}{ D1. Macroeconomic Environment } & \multicolumn{3}{|c|}{ D2. Cost \& Prices } \\
\hline & & 2013 & 1995 & 2013-1995 & 2013 & 1995 & 2013-1995 & 2013 & 1995 & 2013-1995 \\
\hline Singapore & SGP & $5.42(1)$ & $5.09(1)$ & $0.33[0]$ & $5.43(2)$ & $5.78(1)$ & $-0.35[-1]$ & $5.26(69)$ & $5.5(55)$ & $-0.24[-14]$ \\
\hline Luxembourg & LUX & $4.93(2)$ & 3.52 (18) & $1.41[16]$ & $6.73(1)$ & $3.54(2)$ & $3.19[1]$ & $6.12(32)$ & $5.4(60)$ & $0.72[28]$ \\
\hline Sweden & SWE & $4.62(3)$ & $4.2(3)$ & $0.41[0]$ & $2.17(13)$ & $1.48(30)$ & $0.69[17]$ & $5.91(49)$ & $5.41(59)$ & $0.5[10]$ \\
\hline Finland & FIN & $4.56(4)$ & $4.19(4)$ & $0.37[0]$ & $1.53(34)$ & $1.05(61)$ & $0.49[27]$ & $5.53(63)$ & $5.08(69)$ & $0.45[6]$ \\
\hline Denmark & DNK & $4.53(5)$ & $3.88(7)$ & $0.65[2]$ & $2.04(15)$ & $1.44(34)$ & $0.6[19]$ & $4.46(73)$ & $4.68(72)$ & $-0.22[-1]$ \\
\hline Netherlands & NLD & $4.47(6)$ & $3.81(11)$ & $0.66[5]$ & $2.49(8)$ & $2.15(7)$ & $0.34[-1]$ & $5.48(65)$ & $5.13(68)$ & $0.35[3]$ \\
\hline Ireland & IRL & $4.47(7)$ & $3.83(9)$ & $0.64[2]$ & $3.06(5)$ & $2.5(5)$ & $0.56[0]$ & $5.9(50)$ & $5.88(34)$ & $0.02[-16]$ \\
\hline Switzerland & $\mathrm{CHE}$ & $4.45(8)$ & $3.84(8)$ & $0.62[0]$ & $3.09(4)$ & $2.56(4)$ & $0.53[0]$ & $4.47(72)$ & $4.44(73)$ & $0.03[1]$ \\
\hline United States of America & USA & $4.36(9)$ & $4.32(2)$ & $0.05[-7]$ & $1.05(66)$ & $1.53(26)$ & $-0.48[-40]$ & $6.05(38)$ & $5.65(51)$ & $0.39[13]$ \\
\hline Belgium & BEL & $4.32(10)$ & $3.58(16)$ & $0.74[6]$ & $3.13(3)$ & $1.55(24)$ & $1.58[21]$ & $5.62(60)$ & $5.38(62)$ & $0.24[2]$ \\
\hline Israel & ISR & $4.31(11)$ & 3.49 (19) & $0.82[8]$ & $1.48(41)$ & 1.27 (43) & $0.2[2]$ & $5.43(66)$ & $5.48(56)$ & $-0.05[-10]$ \\
\hline Austria & AUT & $4.21(12)$ & $3.58(15)$ & $0.62[3]$ & $1.69(24)$ & $1.15(50)$ & $0.53[26]$ & 5.65 (59) & $5.32(64)$ & $0.33[5]$ \\
\hline Canada & CAN & $4.16(13)$ & $3.94(5)$ & $0.22[-8]$ & $1.58(31)$ & $1.4(36)$ & $0.18[5]$ & $5.79(54)$ & $5.72(50)$ & $0.07[-4]$ \\
\hline Korea, Republic of & KOR & $4.14(14)$ & 3.55 (17) & $0.59[3]$ & $1.91(21)$ & $1.76(15)$ & $0.15[-6]$ & $5.84(52)$ & $5.89(31)$ & $-0.04[-21]$ \\
\hline Germany & $\mathrm{DEU}$ & $4.04(15)$ & $3.63(13)$ & $0.41[-2]$ & $1.64(25)$ & $0.93(66)$ & $0.72[41]$ & $5.24(70)$ & $4.94(70)$ & $0.3[0]$ \\
\hline Japan & JPN & $4.03(16)$ & $3.82(10)$ & $0.21[-6]$ & $0.67(72)$ & $1.38(38)$ & $-0.71[-34]$ & 5.67 (57) & $4.32(75)$ & 1.36 [18] \\
\hline United Kingdom & GBR & 3.95 (17) & $3.59(14)$ & $0.37[-3]$ & 1.49 (39) & $1.58(22)$ & $-0.09[-17]$ & $5.37(68)$ & $5.48(57)$ & $-0.11[-11]$ \\
\hline Australia & AUS & 3.94 (18) & $3.93(6)$ & $0.01[-12]$ & $1.42(44)$ & $1.51(27)$ & $-0.09[-17]$ & $5.23(71)$ & $5.73(49)$ & $-0.5[-22]$ \\
\hline France & FRA & $3.93(19)$ & $3.68(12)$ & $0.25[-7]$ & $1.11(61)$ & $1.17(49)$ & $-0.06[-12]$ & $5.66(58)$ & $5.34(63)$ & $0.33[5]$ \\
\hline Malaysia & MYS & 3.7 (20) & $3.2(20)$ & $0.5[0]$ & $2.36(9)$ & $2.71(3)$ & $-0.35[-6]$ & $6.41(6)$ & $5.82(41)$ & 0.59 [35] \\
\hline United Arab Emirates & ARE & $3.66(21)$ & $3.15(21)$ & $0.51[0]$ & 1.92 (19) & $1.5(28)$ & $0.42[9]$ & $6.3(13)$ & $6.13(15)$ & $0.18[2]$ \\
\hline Estonia & EST & $3.59(22)$ & $2.61(42)$ & $0.99[20]$ & $2.2(11)$ & $2.01(8)$ & $0.19[-3]$ & $6.12(33)$ & $5.19(67)$ & $0.93[34]$ \\
\hline Malta & MLT & $3.58(23)$ & $3.02(24)$ & $0.57[1]$ & $2.93(6)$ & $1.93(10)$ & $1[4]$ & $6.17(26)$ & $6.02(22)$ & $0.15[-4]$ \\
\hline Slovenia & SVN & $3.57(24)$ & $2.81(29)$ & $0.76[5]$ & $1.41(45)$ & $1.6(20)$ & $-0.18[-25]$ & $6.3(14)$ & $5.74(47)$ & $0.56[33]$ \\
\hline Qatar & QAT & 3.49 (25) & $2.92(26)$ & $0.57[1]$ & $2.82(7)$ & 1.7 (18) & $1.12[11]$ & $6.35(11)$ & $6.19(5)$ & {$[-6]$} \\
\hline Czech Republic & $\mathrm{CZE}$ & $3.38(26)$ & $2.76(33)$ & $0.62[7]$ & $1.49(38)$ & $1.76(14)$ & $-0.27[-24]$ & $6.29(15)$ & $6.13(14)$ & $0.16[-1]$ \\
\hline Spain & ESP & 3.34 (27) & 3.06 (23) & $0.28[-4]$ & $0.83(70)$ & $0.68(72)$ & 0.15 [2] & $5.73(56)$ & $5.63(53)$ & $0.1[-3]$ \\
\hline Lithuania & LTU & 3.32 (28) & 2.52 (49) & $0.8[21]$ & $1.43(43)$ & 0.99 (63) & $0.44[20]$ & $6.37(9)$ & 6.12 (19) & $0.25[10]$ \\
\hline Portugal & PRT & 3.25 (29) & $2.86(28)$ & $0.39[-1]$ & $0.82(71)$ & $1.29(41)$ & $-0.47[-30]$ & $6.14(30)$ & $5.88(32)$ & $0.26[2]$ \\
\hline Saudi Arabia & SAU & 3.22 (30) & 2.73 (37) & $0.49[7]$ & $1.91(20)$ & $1.28(42)$ & $0.64[22]$ & $6.14(31)$ & 5.87 (35) & $0.26[4]$ \\
\hline Chile & $\mathrm{CHL}$ & 3.19 (31) & $2.91(27)$ & $0.28[-4]$ & $1.86(22)$ & $1.78(12)$ & $0.08[-10]$ & $6.2(24)$ & $5.82(40)$ & 0.37 [16] \\
\hline Italy & ITA & 3.18 (32) & 3.07 (22) & $0.11[-10]$ & $0.64(73)$ & $0.63(74)$ & $0.01[1]$ & $5.97(44)$ & $5.81(42)$ & $0.16[-2]$ \\
\hline Poland & POL & 3.12 (33) & $2.36(66)$ & $0.76[33]$ & $1.16(57)$ & $1.14(52)$ & $0.01[-5]$ & $6.59(2)$ & $5.39(61)$ & 1.2 [59] \\
\hline Cyprus & CYP & 3.12 (34) & $2.99(25)$ & $0.14[-9]$ & $1.48(40)$ & $2.01(9)$ & $-0.53[-31]$ & $6.16(28)$ & $5.99(24)$ & $0.17[-4]$ \\
\hline Hungary & HUN & 3.08 (35) & $2.5(50)$ & 0.57 [15] & 1.54 (33) & 0.8 (69) & $0.74[36]$ & $6.47(4)$ & $6(23)$ & 0.47 [19] \\
\hline Latvia & LVA & 3.05 (36) & $2.46(52)$ & 0.59 [16] & $1.48(42)$ & $1.31(40)$ & $0.17[-2]$ & $6.25(18)$ & $6.15(11)$ & $0.1[-7]$ \\
\hline Thailand & THA & 3.04 (37) & $2.81(30)$ & $0.23[-7]$ & $2.31(10)$ & $1.91(11)$ & $0.4[1]$ & $6.28(16)$ & $6.24(3)$ & $0.05[-13]$ \\
\hline Slovakia & SVK & $2.93(38)$ & $2.57(44)$ & $0.35[6]$ & $1.38(46)$ & $1.58(23)$ & $-0.2[-23]$ & 6.23 (19) & $5.73(48)$ & 0.5 [29] \\
\hline Greece & GRC & 2.83 (39) & $2.77(32)$ & $0.06[-7]$ & $0(76)$ & $0.46(75)$ & $-0.46[-1]$ & 6.07 (36) & 5.57 (54) & $0.5[18]$ \\
\hline Jordan & JOR & $2.8(40)$ & $2.73(36)$ & $0.06[-4]$ & $1.08(64)$ & $1.73(16)$ & $-0.65[-48]$ & $6.33(12)$ & $6.28(2)$ & $0.05[-10]$ \\
\hline Palestine & PSE & $2.76(41)$ & $2.73(35)$ & $0.03[-6]$ & $0.51(75)$ & $0.82(68)$ & $-0.31[-7]$ & $6.22(22)$ & $6.13(15)$ & $0.09[-7]$ \\
\hline Turkey & TUR & $2.73(42)$ & $2.42(57)$ & 0.31 [15] & 0.87 (69) & $1.25(45)$ & $-0.38[-24]$ & $6(43)$ & $4.43(74)$ & $1.56[31]$ \\
\hline Mexico & MEX & $2.73(43)$ & $2.46(51)$ & $0.26[8]$ & $1.34(48)$ & $1.06(60)$ & $0.28[12]$ & $6.35(10)$ & $5.81(44)$ & $0.54[34]$ \\
\hline Lebanon & $\mathrm{LBN}$ & $2.7(44)$ & $2.79(31)$ & $-0.09[-13]$ & 2.07 (14) & $1.2(46)$ & 0.87 [32] & $6.22(21)$ & $6.13(15)$ & $0.1[-6]$ \\
\hline Kazakhstan & KAZ & $2.69(45)$ & 2.37 (64) & 0.33 [19] & $1.73(23)$ & $1.11(54)$ & $0.62[31]$ & $6.84(1)$ & 5.88 (33) & 0.96 [32] \\
\hline Libya & LBY & $2.68(46)$ & $2.61(41)$ & $0.07[-5]$ & 2.03 (17) & $1.18(47)$ & 0.85 [30] & $6.11(34)$ & $6.18(6)$ & $-0.07[-28]$ \\
\hline Tunisia & TUN & 2.67 (47) & 2.59 (43) & $0.08[-4]$ & $1.15(58)$ & 1.35 (39) & $-0.2[-19]$ & $6.03(42)$ & $5.84(37)$ & $0.19[-5]$ \\
\hline China & $\mathrm{CHN}$ & $2.65(48)$ & $2.43(56)$ & $0.23[8]$ & $1.6(28)$ & $1.7(17)$ & $-0.1[-11]$ & $5.52(64)$ & $5.92(28)$ & $-0.41[-36]$ \\
\hline Viet Nam & VNM & 2.57 (49) & $2.55(47)$ & $0.02[-2]$ & $2.04(16)$ & $1.77(13)$ & $0.27[-3]$ & $5.93(46)$ & $6.13(15)$ & $-0.2[-31]$ \\
\hline Russian Federation & RUS & $2.56(50)$ & $1.87(75)$ & $0.7[25]$ & $1.61(27)$ & $1.1(56)$ & 0.52 [29] & $6.1(35)$ & $5.65(52)$ & $0.44[17]$ \\
\hline Morocco & MAR & $2.56(51)$ & $2.4(61)$ & $0.16[10]$ & $1.17(56)$ & $0.95(64)$ & $0.22[8]$ & $6.26(17)$ & $5.92(29)$ & $0.34[12]$ \\
\hline Georgia & GEO & $2.56(52)$ & $2.36(65)$ & $0.2[13]$ & $1.53(35)$ & $1.15(51)$ & $0.38[16]$ & $6.19(25)$ & $5.76(46)$ & $0.44[21]$ \\
\hline Philippines & PHL & $2.56(53)$ & $2.75(34)$ & $-0.19[-19]$ & $1.55(32)$ & $1.48(32)$ & $0.07[0]$ & $6.06(37)$ & $5.85(36)$ & $0.21[-1]$ \\
\hline Azerbaijan & AZE & $2.55(54)$ & $2.33(68)$ & $0.23[14]$ & $2.18(12)$ & $0.74(70)$ & $1.44[58]$ & $6.39(7)$ & $5.46(58)$ & $0.94[51]$ \\
\hline Armenia & ARM & $2.5(55)$ & $2.21(74)$ & $0.29[19]$ & $1.2(53)$ & $0.33(76)$ & $0.87[23]$ & $6.04(40)$ & $5.81(43)$ & $0.23[3]$ \\
\hline Bulgaria & BGR & $2.48(56)$ & $2.55(46)$ & $-0.07[-10]$ & $1.58(30)$ & 1.12 (53) & $0.46[23]$ & $6.49(3)$ & $6.04(21)$ & $0.45[18]$ \\
\hline Argentina & ARG & $2.45(57)$ & 2.68 (39) & $-0.23[-18]$ & $1.06(65)$ & $0.67(73)$ & 0.39 [8] & $5.59(61)$ & $5.96(26)$ & $-0.36[-35]$ \\
\hline Brazil & BRA & $2.45(58)$ & $2.43(55)$ & $0.02[-3]$ & $1.1(62)$ & $1.11(55)$ & $0[-7]$ & $6.16(27)$ & $5.28(66)$ & 0.89 [39] \\
\hline Colombia & COL & 2.44 (59) & $2.37(63)$ & $0.07[4]$ & $1.25(49)$ & $0.88(67)$ & 0.37 [18] & $5.91(48)$ & $5.97(25)$ & $-0.05[-23]$ \\
\hline Indonesia & IDN & $2.43(60)$ & $2.41(60)$ & $0.02[0]$ & $1.36(47)$ & $1.58(21)$ & $-0.23[-26]$ & $6.47(5)$ & $5.91(30)$ & $0.56[25]$ \\
\hline Peru & PER & $2.43(61)$ & $2.53(48)$ & $-0.1[-13]$ & 1.59 (29) & $1.08(59)$ & 0.52 [30] & $6.22(23)$ & $6.17(9)$ & $0.04[-14]$ \\
\hline Romania & ROU & $2.38(62)$ & $2.44(54)$ & $-0.07[-8]$ & $1.1(63)$ & 1.17 (48) & $-0.07[-15]$ & $6.23(20)$ & $6.1(20)$ & 0.12 [0] \\
\hline Moldova & MDA & $2.38(63)$ & $2.41(59)$ & $-0.04[-4]$ & $1.23(52)$ & $1.4(35)$ & $-0.17[-17]$ & $5.83(53)$ & $5.94(27)$ & $-0.11[-26]$ \\
\hline Egypt & EGY & $2.31(64)$ & $2.56(45)$ & $-0.26[-19]$ & $0.63(74)$ & $1.53(25)$ & $-0.91[-49]$ & 6.05 (39) & $6.16(10)$ & $-0.12[-29]$ \\
\hline South Africa & ZAF & $2.29(65)$ & $2.29(71)$ & $0[6]$ & 0.89 (68) & $1.44(33)$ & $-0.54[-35]$ & $6.16(29)$ & $5.84(38)$ & 0.32 [9] \\
\hline Belarus & BLR & $2.27(66)$ & $2.39(62)$ & $-0.13[-4]$ & 1.51 (37) & $0.93(65)$ & 0.58 [28] & 3.05 (76) & $4.93(71)$ & $-1.87[-5]$ \\
\hline Algeria & DZA & $2.26(67)$ & $2.35(67)$ & $-0.08[0]$ & $1.25(51)$ & $0.69(71)$ & 0.56 [20] & 5.75 (55) & $5.8(45)$ & $-0.05[-10]$ \\
\hline Ukraine & UKR & $2.25(68)$ & $2.3(70)$ & $-0.05[2]$ & $1.11(60)$ & 1.09 (57) & $0.02[-3]$ & $6.03(41)$ & $5.31(65)$ & $0.72[24]$ \\
\hline Senegal & SEN & $2.16(69)$ & $2.42(58)$ & $-0.26[-11]$ & $1.18(55)$ & $1.38(37)$ & $-0.2[-18]$ & $6.37(8)$ & $6.18(7)$ & $0.19[-1]$ \\
\hline Syrian Arab Republic (Syria) & SYR & $2.15(70)$ & $2.68(38)$ & $-0.54[-32]$ & $1.19(54)$ & $1.66(19)$ & $-0.47[-35]$ & $4.35(74)$ & $6.18(8)$ & $-1.83[-66]$ \\
\hline Iran, Islamic Republic of & IRN & $2.14(71)$ & $2.62(40)$ & $-0.48[-31]$ & $1.12(59)$ & $1.27(44)$ & $-0.15[-15]$ & $4.33(75)$ & $6.14(13)$ & $-1.81[-62]$ \\
\hline India & IND & $2.04(72)$ & $2.46(53)$ & $-0.41[-19]$ & $1.25(50)$ & $1.08(58)$ & $0.16[8]$ & $5.95(45)$ & $6.34(1)$ & $-0.39[-44]$ \\
\hline Kenya & KEN & $2(73)$ & $2.31(69)$ & $-0.31[-4]$ & $1(67)$ & $1.03(62)$ & $-0.03[-5]$ & $5.92(47)$ & $6.19(4)$ & $-0.27[-43]$ \\
\hline Tanzania, United Republic of & $\mathrm{TZA}$ & $1.95(74)$ & $2.22(73)$ & $-0.27[-1]$ & $1.52(36)$ & $1.48(31)$ & $0.04[-5]$ & $5.54(62)$ & $6.14(12)$ & $-0.61[-50]$ \\
\hline Angola & AGO & $1.94(75)$ & $1.71(76)$ & $0.22[1]$ & 2.01 (18) & $2.17(6)$ & $-0.17[-12]$ & $5.86(51)$ & $1.42(76)$ & $4.44[25]$ \\
\hline Nigeria & NGA & $1.88(76)$ & $2.28(72)$ & $-0.41[-4]$ & $1.64(26)$ & $1.49(29)$ & 0.15 [3] & $5.42(67)$ & $5.83(39)$ & $-0.41[-28]$ \\
\hline
\end{tabular}

Note: Rank order in parenthesis. Difference in rank order in brackets. 
Table A.3. ISEPI Global Indicator and Dimensions. 1995-2013 (2/3)

\begin{tabular}{|c|c|c|c|c|c|c|c|c|c|c|}
\hline \multirow[b]{2}{*}{ Country } & \multirow[b]{2}{*}{ ISO } & \multicolumn{3}{|c|}{ D3. Productivity and human capital } & \multicolumn{3}{|c|}{$\begin{array}{l}\text { D4. Technological and innovative } \\
\text { capital }\end{array}$} & \multicolumn{3}{|c|}{ D5. Market potential } \\
\hline & & 2013 & 1995 & 2013-1995 & 2013 & 1995 & 2013-1995 & 2013 & 1995 & 2013-1995 \\
\hline Singapore & SGP & $3.29(30)$ & $2.77(31)$ & $0.52[1]$ & $5.17(4)$ & $5.14(5)$ & $0.03[1]$ & $6.5(1)$ & $6.86(1)$ & $-0.36[0]$ \\
\hline Luxembourg & LUX & $4.35(17)$ & 3.47 (19) & $0.88[2]$ & $3.85(16)$ & $2.39(20)$ & $1.46[4]$ & $2.26(4)$ & $1.86(7)$ & 0.4 [3] \\
\hline Sweden & SWE & $5.87(4)$ & $5.54(3)$ & $0.34[-1]$ & $4.84(8)$ & $6.62(3)$ & $-1.78[-5]$ & $1.19(46)$ & $0.96(53)$ & 0.24 [7] \\
\hline Finland & FIN & $6.27(2)$ & $5.79(1)$ & $0.49[-1]$ & $5.2(3)$ & $7(1)$ & $-1.8[-2]$ & $1.11(51)$ & $0.99(51)$ & $0.11[0]$ \\
\hline Denmark & DNK & $6.74(1)$ & $5.5(4)$ & $1.25[3]$ & $4.57(10)$ & $4.68(6)$ & $-0.12[-4]$ & $1.24(40)$ & $1.23(38)$ & $0.01[-2]$ \\
\hline Netherlands & NLD & $5.54(6)$ & $4.94(8)$ & $0.6[2]$ & $4.3(13)$ & $4.22(9)$ & $0.08[-4]$ & $1.46(18)$ & $1.48(19)$ & $-0.02[1]$ \\
\hline Switzerland & $\mathrm{CHE}$ & $4.9(10)$ & 3.95 (17) & $0.94[7]$ & $5.14(5)$ & $3.75(13)$ & $1.39[8]$ & $1.42(22)$ & $1.34(30)$ & $0.07[8]$ \\
\hline United States of America & USA & $4.85(11)$ & $4.8(9)$ & $0.05[-2]$ & $4.88(7)$ & $6.79(2)$ & $-1.91[-5]$ & $1.52(14)$ & $1.47(20)$ & $0.06[6]$ \\
\hline Belgium & BEL & $5.11(7)$ & $5.11(6)$ & $0[-1]$ & 3.59 (19) & $2.81(18)$ & $0.78[-1]$ & 1.49 (17) & $1.2(42)$ & $0.29[25]$ \\
\hline Israel & ISR & $5.9(3)$ & $3.44(20)$ & $2.46[17]$ & $5(6)$ & $3.42(15)$ & $1.58[9]$ & $1.79(8)$ & $1.89(6)$ & $-0.1[-2]$ \\
\hline Austria & AUT & $4.9(9)$ & $4.27(14)$ & $0.63[5]$ & $4.46(11)$ & $2.72(19)$ & $1.74[8]$ & $1.05(52)$ & $0.95(55)$ & $0.1[3]$ \\
\hline Canada & CAN & $4.81(12)$ & $5.55(2)$ & $-0.74[-10]$ & $3.33(22)$ & $4.11(12)$ & $-0.79[-10]$ & $1.35(27)$ & $1.21(40)$ & 0.14 [13] \\
\hline Korea, Republic of & KOR & $4.62(15)$ & $3.6(18)$ & $1.02[3]$ & $6.85(1)$ & $4.18(10)$ & $2.67[9]$ & $1.5(16)$ & $1.71(10)$ & $-0.21[-6]$ \\
\hline Germany & DEU & $4.35(18)$ & $4.68(10)$ & $-0.33[-8]$ & $4.59(9)$ & $3.75(14)$ & $0.83[5]$ & $0.71(65)$ & $1.17(44)$ & $-0.46[-21]$ \\
\hline Japan & JPN & $4(20)$ & $4.6(11)$ & $-0.6[-9]$ & $5.68(2)$ & $6.14(4)$ & $-0.46[2]$ & $1.03(54)$ & $1.35(28)$ & $-0.32[-26]$ \\
\hline Australia & AUS & $5.01(8)$ & $5.1(7)$ & $-0.09[-1]$ & $3.5(20)$ & $4.15(11)$ & $-0.65[-9]$ & $1.56(11)$ & $1.34(32)$ & $0.22[21]$ \\
\hline France & FRA & $4.66(13)$ & $5.14(5)$ & $-0.48[-8]$ & $3.92(14)$ & $3.36(16)$ & $0.57[2]$ & $1.21(44)$ & $1.06(49)$ & 0.15 [5] \\
\hline Malaysia & MYS & $2.58(44)$ & $2.06(50)$ & $0.52[6]$ & $3.91(15)$ & $2.89(17)$ & $1.01[2]$ & $1.53(13)$ & $1.56(12)$ & $-0.04[-1]$ \\
\hline United Arab Emirates & ARE & $1.81(57)$ & $2.22(47)$ & $-0.41[-10]$ & $2.81(26)$ & $1.86(25)$ & $0.95[-1]$ & $2.43(3)$ & $3.57(2)$ & $-1.13[-1]$ \\
\hline Estonia & EST & $3.68(24)$ & $3.12(23)$ & $0.55[-1]$ & 3.67 (18) & $1.73(26)$ & $1.94[8]$ & $0.69(66)$ & $0.27(75)$ & 0.42 [9] \\
\hline Malta & MLT & 3.08 (35) & $2.31(42)$ & $0.77[7]$ & $3.35(21)$ & $1.58(32)$ & $1.77[11]$ & $1.95(7)$ & $2.23(4)$ & $-0.28[-3]$ \\
\hline Slovenia & SVN & $4.62(14)$ & $3.31(22)$ & $1.31[8]$ & $2.81(27)$ & $1.9(24)$ & $0.9[-3]$ & $0.76(63)$ & $0.73(64)$ & $0.03[1]$ \\
\hline Qatar & QAT & $1.55(62)$ & $2.24(46)$ & $-0.69[-16]$ & 2.06 (39) & $1.39(42)$ & $0.67[3]$ & $4.16(2)$ & $1.59(11)$ & 2.57 [9] \\
\hline Czech Republic & CZE & $3.6(27)$ & $3.11(24)$ & $0.49[-3]$ & $2.98(23)$ & $1.65(30)$ & $1.33[7]$ & $0.97(57)$ & $0.88(58)$ & $0.09[1]$ \\
\hline Spain & ESP & $4.43(16)$ & 3.99 (15) & $0.44[-1]$ & $2.18(36)$ & $1.59(31)$ & $0.59[-5]$ & $0.98(56)$ & $0.92(57)$ & $0.05[1]$ \\
\hline Lithuania & LTU & $3.72(23)$ & $2.57(36)$ & $1.15[13]$ & $2.63(29)$ & $1.26(54)$ & 1.37 [25] & 0.57 (74) & $0.53(69)$ & $0.04[-5]$ \\
\hline Portugal & PRT & $3.63(26)$ & $3.05(26)$ & $0.57[0]$ & $2.16(37)$ & $1.54(34)$ & $0.62[-3]$ & 0.67 (67) & $0.74(63)$ & $-0.07[-4]$ \\
\hline Saudi Arabia & SAU & $3.27(31)$ & $2.7(32)$ & $0.57[1]$ & $2.31(31)$ & $0.99(73)$ & $1.31[42]$ & $1.99(6)$ & $1.9(5)$ & $0.08[-1]$ \\
\hline Chile & CHL & $2.77(40)$ & $2.65(34)$ & $0.12[-6]$ & $1.86(42)$ & $1.19(58)$ & $0.67[16]$ & 1.32 (31) & $1.41(23)$ & $-0.1[-8]$ \\
\hline Italy & ITA & $3.65(25)$ & 3.97 (16) & $-0.32[-9]$ & $2.86(25)$ & $2.17(21)$ & $0.68[-4]$ & $0.51(75)$ & 0.95 (54) & $-0.44[-21]$ \\
\hline Poland & POL & $3.76(22)$ & 3.06 (25) & $0.71[3]$ & $1.88(41)$ & $1.05(66)$ & 0.83 [25] & 0.86 (59) & $0.82(61)$ & 0.05 [2] \\
\hline Cyprus & CYP & $3.23(32)$ & 2.77 (30) & $0.46[-2]$ & $1.76(44)$ & $1.68(28)$ & $0.08[-16]$ & 1.29 (34) & 1.49 (18) & $-0.2[-16]$ \\
\hline Hungary & HUN & 2.99 (37) & 2.92 (29) & $0.07[-8]$ & $2.8(28)$ & $1.56(33)$ & 1.24 [5] & $0.73(64)$ & 0.7 (65) & 0.03 [1] \\
\hline Slovakia & SVK & 2.79 (39) & 2.66 (33) & $0.13[-6]$ & 2.27 (33) & $1.2(56)$ & 1.07 [23] & 0.91 (58) & $0.83(60)$ & $0.08[2]$ \\
\hline Greece & GRC & $3.86(21)$ & $2.95(27)$ & $0.92[6]$ & 1.67 (47) & 1.29 (53) & 0.38 [6] & 0.66 (69) & 0.86 (59) & $-0.2[-10]$ \\
\hline Jordan & JOR & 3.41 (29) & $1.85(62)$ & 1.56 [33] & 1.07 (64) & $1.24(55)$ & $-0.17[-9]$ & $1.62(9)$ & $1.8(8)$ & $-0.18[-1]$ \\
\hline Palestine & PSE & $2.31(48)$ & $1.84(63)$ & $0.47[15]$ & $1.47(52)$ & 1.66 (29) & $-0.19[-23]$ & 2.11 (5) & 2.39 (3) & $-0.28[-2]$ \\
\hline Turkey & TUR & $2.59(43)$ & $2.31(41)$ & $0.28[-2]$ & $0.91(65)$ & $0.94(74)$ & $-0.03[9]$ & $1.36(26)$ & $1.34(31)$ & $0.02[5]$ \\
\hline Mexico & MEX & 2.08 (53) & $2.02(52)$ & $0.06[-1]$ & $1.12(62)$ & $1.2(57)$ & $-0.08[-5]$ & $1.4(23)$ & $1.53(15)$ & $-0.13[-8]$ \\
\hline Lebanon & LBN & $1.44(67)$ & $1.94(56)$ & $-0.5[-11]$ & $1.37(54)$ & $1.73(27)$ & $-0.36[-27]$ & $1.52(15)$ & $1.74(9)$ & $-0.21[-6]$ \\
\hline Kazakhstan & KAZ & $2.16(52)$ & $2.27(45)$ & $-0.11[-7]$ & $2.96(24)$ & $1.17(62)$ & $1.79[38]$ & $1.23(42)$ & $0.39(72)$ & $0.84[30]$ \\
\hline Libya & LBY & $2.27(49)$ & $1.72(65)$ & $0.54[16]$ & $1.79(43)$ & $1.42(40)$ & $0.37[-3]$ & $1.3(33)$ & $1.49(17)$ & $-0.19[-16]$ \\
\hline Tunisia & TUN & $2.45(45)$ & 2.38 (39) & $0.07[-6]$ & $1.46(53)$ & $1.04(67)$ & $0.42[14]$ & $1.14(50)$ & $1.24(37)$ & $-0.09[-13]$ \\
\hline China & $\mathrm{CHN}$ & $1.66(59)$ & $0.9(75)$ & $0.76[16]$ & $2.27(34)$ & $1.32(50)$ & $0.95[16]$ & $1.28(35)$ & $1.25(35)$ & $0.02[0]$ \\
\hline Viet Nam & VNM & $1.46(65)$ & $1.28(73)$ & $0.18[8]$ & $2.08(38)$ & $1.42(39)$ & $0.66[1]$ & $0.98(55)$ & $1.03(50)$ & $-0.05[-5]$ \\
\hline Russian Federation & RUS & 3.07 (36) & $3.43(21)$ & $-0.36[-15]$ & $2.54(30)$ & $1.19(60)$ & $1.35[30]$ & $1.05(53)$ & $0.76(62)$ & 0.29 [9] \\
\hline Morocco & MAR & $1.47(64)$ & $1.91(59)$ & $-0.45[-5]$ & $1.7(46)$ & $1.01(70)$ & $0.7[24]$ & 1.19 (47) & $1.17(45)$ & $0.02[-2]$ \\
\hline Georgia & GEO & $1.29(69)$ & $2.17(48)$ & $-0.88[-21]$ & $1.31(57)$ & $1.35(48)$ & $-0.05[-9]$ & $0.62(72)$ & $0(76)$ & $0.62[4]$ \\
\hline Philippines & PHL & $1.6(61)$ & $2.5(37)$ & $-0.9[-24]$ & $2.3(32)$ & $2.04(22)$ & $0.26[-10]$ & $1.37(24)$ & $1.51(16)$ & $-0.14[-8]$ \\
\hline Azerbaijan & AZE & $1.5(63)$ & $2.01(55)$ & $-0.51[-8]$ & $1.6(48)$ & $1.33(49)$ & $0.26[1]$ & $1.24(41)$ & $1.08(48)$ & 0.15 [7] \\
\hline Armenia & ARM & $2.2(50)$ & $1.6(67)$ & 0.6 [17] & $1.28(59)$ & $1.35(47)$ & $-0.08[-12]$ & $0.85(61)$ & $0.36(73)$ & 0.49 [12] \\
\hline Bulgaria & BGR & $1.81(58)$ & $2.58(35)$ & $-0.77[-23]$ & $1.59(49)$ & $1.37(44)$ & $0.22[-5]$ & 0.59 (73) & $0.5(70)$ & $0.09[-3]$ \\
\hline Argentina & ARG & 3.14 (34) & $2.28(44)$ & $0.86[10]$ & $1.93(40)$ & $0.8(76)$ & $1.12[36]$ & 1.24 (38) & $1.21(41)$ & 0.03 [3] \\
\hline Brazil & BRA & $1.4(68)$ & $2.46(38)$ & $-1.06[-30]$ & $1.72(45)$ & 1.02 (69) & $0.7[24]$ & 1.32 (29) & $1.42(22)$ & $-0.1[-7]$ \\
\hline Colombia & COL & $2.45(46)$ & $2.01(54)$ & $0.43[8]$ & $1.1(63)$ & $1.03(68)$ & $0.07[5]$ & $1.32(30)$ & $1.4(25)$ & $-0.08[-5]$ \\
\hline Indonesia & IDN & $1.18(71)$ & $1.2(74)$ & $-0.03[3]$ & $0.73(70)$ & $1.16(63)$ & $-0.43[-7]$ & 1.22 (43) & $1.18(43)$ & $0.04[0]$ \\
\hline Peru & PER & $1.44(66)$ & $1.92(58)$ & $-0.47[-8]$ & $0.49(74)$ & $1.18(61)$ & $-0.69[-13]$ & $1.3(32)$ & $1.36(27)$ & $-0.06[-5]$ \\
\hline Romania & ROU & $2.06(54)$ & $2.04(51)$ & $0.02[-3]$ & $1.26(60)$ & $1.09(65)$ & $0.18[5]$ & $0.62(71)$ & $0.62(66)$ & $0.01[-5]$ \\
\hline Moldova & MDA & $2.61(42)$ & $2.01(53)$ & 0.59 [11] & $1.28(58)$ & $1.15(64)$ & $0.13[6]$ & $0.64(70)$ & $0.53(68)$ & $0.11[-2]$ \\
\hline Egypt & EGY & $1.64(60)$ & $2.29(43)$ & $-0.65[-17]$ & 1.35 (56) & $1.01(71)$ & 0.34 [15] & 1.17 (49) & $1.11(46)$ & $0.05[-3]$ \\
\hline South Africa & ZAF & $1.81(56)$ & $1.54(68)$ & $0.27[12]$ & $1.37(55)$ & $1.54(35)$ & $-0.17[-20]$ & $1.24(37)$ & $1.4(24)$ & $-0.16[-13]$ \\
\hline Belarus & BLR & $3.55(28)$ & $2.94(28)$ & $0.6[0]$ & $1.52(51)$ & $1.35(46)$ & $0.16[-5]$ & $0.86(60)$ & $0.57(67)$ & $0.29[7]$ \\
\hline Algeria & DZA & $1.94(55)$ & $1.64(66)$ & $0.31[11]$ & $0.64(72)$ & $1(72)$ & $-0.36[0]$ & 1.45 (19) & $1.34(29)$ & $0.1[10]$ \\
\hline Ukraine & UKR & $3.16(33)$ & $1.94(57)$ & $1.22[24]$ & $1.15(61)$ & $1.38(43)$ & $-0.23[-18]$ & $0.66(68)$ & $0.46(71)$ & $0.2[3]$ \\
\hline Senegal & SEN & $0.75(73)$ & $1.51(69)$ & $-0.76[-4]$ & $0.73(69)$ & $1.4(41)$ & $-0.67[-28]$ & $1.37(25)$ & $1.33(33)$ & $0.03[8]$ \\
\hline Syrian Arab Republic (Syria) & SYR & $2.31(47)$ & $1.83(64)$ & $0.49[17]$ & $0.36(75)$ & $1.32(51)$ & $-0.96[-24]$ & $1.44(20)$ & $1.55(13)$ & $-0.11[-7]$ \\
\hline Iran, Islamic Republic of & IRN & $2.18(51)$ & $2.32(40)$ & $-0.14[-11]$ & $0.73(68)$ & $1.31(52)$ & $-0.58[-16]$ & $1.35(28)$ & $1.27(34)$ & $0.07[6]$ \\
\hline India & IND & $1.01(72)$ & $1.89(60)$ & $-0.88[-12]$ & $0(76)$ & $0.94(75)$ & $-0.94[-1]$ & $1.44(21)$ & $1.55(14)$ & $-0.11[-7]$ \\
\hline
\end{tabular}

Note: Rank order in parenthesis. Difference in rank order in brackets. 
Table A.3. ISEPI Global Indicator and Dimensions. 1995-2013 (3/3)

\begin{tabular}{|c|c|c|c|c|c|c|c|}
\hline \multirow[b]{2}{*}{ Country } & \multirow[b]{2}{*}{ ISO } & \multicolumn{3}{|c|}{ D6. Quality of life and labour market conditions } & \multicolumn{3}{|c|}{ D7. Business-friendly environment } \\
\hline & & 2013 & 1995 & 2013-1995 & 2013 & 1995 & 2013-1995 \\
\hline Singapore & SGP & $6.88(1)$ & $3.8(12)$ & $3.09[11]$ & $5.38(16)$ & $5.76(11)$ & $-0.38[-5]$ \\
\hline Luxembourg & LUX & $4.93(24)$ & $2.37(75)$ & $2.55[51]$ & $6.24(4)$ & $5.57(12)$ & $0.67[8]$ \\
\hline Sweden & SWE & $6.22(4)$ & $3.56(61)$ & $2.66[57]$ & $6.11(8)$ & $5.86(7)$ & $0.25[-1]$ \\
\hline Finland & FIN & $6.34(2)$ & $3.86(9)$ & $2.49[7]$ & $5.94(10)$ & $5.56(13)$ & $0.38[3]$ \\
\hline Denmark & DNK & $6.12(5)$ & $3.81(10)$ & $2.31[5]$ & $6.52(3)$ & $5.83(8)$ & $0.69[5]$ \\
\hline Netherlands & NLD & $5.83(6)$ & $3.5(66)$ & $2.33[60]$ & $6.19(7)$ & $5.23(15)$ & $0.96[8]$ \\
\hline Ireland & IRL & $5.8(7)$ & 3.54 (62) & 2.26 [55] & $5.86(11)$ & 5.11 (17) & 0.75 [6] \\
\hline Switzerland & CHE & $5.35(20)$ & $3.86(8)$ & $1.49[-12]$ & $6.81(1)$ & $6.94(1)$ & $-0.13[0]$ \\
\hline United States of America & USA & $5.66(10)$ & $3.66(55)$ & $2[45]$ & $6.53(2)$ & $6.31(3)$ & $0.21[1]$ \\
\hline Belgium & BEL & $5.62(11)$ & $3.64(58)$ & $1.97[47]$ & $5.68(14)$ & $5.34(14)$ & $0.34[0]$ \\
\hline Israel & ISR & $5.54(14)$ & $3.8(12)$ & $1.74[-2]$ & $5.05(18)$ & $5.14(16)$ & $-0.09[-2]$ \\
\hline Austria & AUT & $5.47(17)$ & $3.94(4)$ & $1.52[-13]$ & $6.23(6)$ & $6.72(2)$ & $-0.49[-4]$ \\
\hline Canada & CAN & $6.28(3)$ & $3.54(63)$ & $2.74[60]$ & $6.02(9)$ & $6.09(4)$ & $-0.07[-5]$ \\
\hline Korea, Republic of & KOR & $4.84(26)$ & 3.62 (59) & $1.22[33]$ & $3.43(29)$ & $4.09(23)$ & $-0.66[-6]$ \\
\hline Germany & DEU & $5.54(15)$ & $4.06(2)$ & $1.47[-13]$ & $6.23(5)$ & $5.91(5)$ & $0.32[0]$ \\
\hline Japan & JPN & $5.43(18)$ & $3.2(72)$ & $2.23[54]$ & $5.77(13)$ & $5.76(10)$ & $0[-3]$ \\
\hline United Kingdom & GBR & $5.7(9)$ & $3.44(67)$ & $2.26[58]$ & $5.23(17)$ & $4.51(20)$ & $0.72[3]$ \\
\hline Australia & AUS & $5.11(22)$ & $3.8(12)$ & $1.31[-10]$ & $5.78(12)$ & $5.9(6)$ & $-0.12[-6]$ \\
\hline France & FRA & $5.54(13)$ & $3.91(6)$ & $1.64[-7]$ & $5.41(15)$ & $5.8(9)$ & $-0.39[-6]$ \\
\hline Malaysia & MYS & $5.18(21)$ & $2.93(74)$ & $2.25[53]$ & $3.93(24)$ & $4.42(22)$ & $-0.48[-2]$ \\
\hline United Arab Emirates & ARE & $5.71(8)$ & $3.8(12)$ & $1.91[4]$ & 4.61 (19) & $2.98(31)$ & $1.63[12]$ \\
\hline Estonia & EST & $5.53(16)$ & $3.65(57)$ & $1.87[41]$ & $3.25(32)$ & $2.26(48)$ & 0.99 [16] \\
\hline Malta & MLT & $4.26(39)$ & $3.8(12)$ & $0.46[-27]$ & $3.32(31)$ & 3.24 (29) & $0.08[-2]$ \\
\hline Slovenia & SVN & $5.59(12)$ & $3.8(12)$ & $1.8[0]$ & 3.52 (28) & $2.61(35)$ & $0.92[7]$ \\
\hline Qatar & QAT & $4.52(34)$ & 3.8 (12) & $0.72[-22]$ & $2.96(38)$ & 3.53 (27) & $-0.57[-11]$ \\
\hline Czech Republic & CZE & $4.26(38)$ & 3.02 (73) & $1.24[35]$ & $4.04(22)$ & $2.76(34)$ & $1.27[12]$ \\
\hline Spain & ESP & $4.64(30)$ & 3.87 (7) & $0.77[-23]$ & $4.57(20)$ & $4.74(18)$ & $-0.17[-2]$ \\
\hline Lithuania & LTU & $5.11(23)$ & $3.8(12)$ & $1.31[-11]$ & $3.38(30)$ & $2.34(45)$ & 1.04 [15] \\
\hline Portugal & PRT & 5.37 (19) & 3.7 (54) & 1.67 [35] & 3.95 (23) & $3.83(24)$ & 0.12 [1] \\
\hline Saudi Arabia & SAU & $4.41(35)$ & 3.8 (12) & $0.61[-23]$ & $2.53(42)$ & $2.56(36)$ & $-0.02[-6]$ \\
\hline Chile & CHL & $4.55(31)$ & $3.8(12)$ & $0.75[-19]$ & 3.8 (25) & $3.74(26)$ & $0.07[1]$ \\
\hline Italy & ITA & $4.34(37)$ & 3.38 (69) & $0.96[32]$ & $4.28(21)$ & 4.58 (19) & $-0.3[-2]$ \\
\hline Poland & POL & $4.85(25)$ & $3.53(64)$ & 1.32 [39] & $2.76(40)$ & $1.54(68)$ & 1.22 [28] \\
\hline Cyprus & CYP & $4.78(27)$ & $3.8(12)$ & $0.99[-15]$ & 3.17 (34) & 3.17 (30) & $0[-4]$ \\
\hline Hungary & HUN & $4.55(32)$ & $3.81(11)$ & $0.74[-21]$ & $2.45(44)$ & $1.72(67)$ & $0.73[23]$ \\
\hline Latvia & LVA & $4.77(28)$ & $3.8(12)$ & $0.97[-16]$ & 3.17 (33) & $2.13(57)$ & $1.04[24]$ \\
\hline Thailand & THA & 4.53 (33) & 3.35 (70) & 1.19 [37] & 3.1 (35) & 3.41 (28) & $-0.31[-7]$ \\
\hline Slovakia & SVK & $3.91(50)$ & $3.8(12)$ & $0.12[-38]$ & $3.01(36)$ & $2.22(51)$ & 0.8 [15] \\
\hline Greece & GRC & 3.98 (47) & 3.78 (53) & $0.21[6]$ & 3.57 (27) & $4.51(21)$ & $-0.94[-6]$ \\
\hline Jordan & JOR & 3.95 (48) & 3.8 (12) & $0.16[-36]$ & 2.12 (57) & $2.43(43)$ & $-0.31[-14]$ \\
\hline Palestine & PSE & $3.04(60)$ & 3.8 (12) & $-0.76[-48]$ & 3.65 (26) & 2.49 (37) & 1.15 [11] \\
\hline Turkey & TUR & 4.39 (36) & 3.8 (12) & $0.59[-24]$ & 2.99 (37) & 2.88 (33) & $0.11[-4]$ \\
\hline Mexico & MEX & $4.26(40)$ & 3.8 (12) & $0.46[-28]$ & $2.56(41)$ & $1.84(66)$ & 0.72 [25] \\
\hline Lebanon & LBN & $3.41(53)$ & 3.8 (12) & $-0.39[-41]$ & 2.88 (39) & $2.98(32)$ & $-0.1[-7]$ \\
\hline Kazakhstan & KAZ & $1.94(76)$ & 3.8 (12) & $-1.86[-64]$ & 1.99 (62) & $1.95(63)$ & $0.04[1]$ \\
\hline Libya & LBY & $2.91(64)$ & 3.8 (12) & $-0.89[-52]$ & $2.37(48)$ & $2.47(40)$ & $-0.1[-8]$ \\
\hline Tunisia & TUN & $4.01(44)$ & 3.8 (12) & $0.22[-32]$ & $2.42(45)$ & 2.47 (38) & $-0.05[-7]$ \\
\hline China & $\mathrm{CHN}$ & $4(45)$ & 3.99 (3) & $0.02[-42]$ & $2.26(53)$ & $1.89(64)$ & $0.36[11]$ \\
\hline Viet Nam & VNM & $3.16(58)$ & 3.8 (12) & $-0.64[-46]$ & 2.35 (49) & $2.42(44)$ & $-0.07[-5]$ \\
\hline Russian Federation & RUS & $2.37(74)$ & $0.45(76)$ & $1.91[2]$ & 1.22 (69) & $0.48(74)$ & $0.74[5]$ \\
\hline Morocco & MAR & $4.16(42)$ & $3.8(12)$ & $0.37[-30]$ & $1.99(61)$ & $2.05(61)$ & $-0.06[0]$ \\
\hline Georgia & GEO & 4.69 (29) & $3.8(12)$ & $0.9[-17]$ & $2.3(50)$ & $2.31(46)$ & $0[-4]$ \\
\hline Philippines & PHL & $2.88(66)$ & $3.6(60)$ & $-0.72[-6]$ & $2.17(56)$ & $2.25(49)$ & $-0.08[-7]$ \\
\hline Azerbaijan & AZE & $2.94(63)$ & $3.8(12)$ & $-0.86[-51]$ & $2.04(58)$ & $1.87(65)$ & $0.17[7]$ \\
\hline Armenia & ARM & $3.66(52)$ & 3.8 (12) & $-0.14[-40]$ & $2.28(51)$ & $2.19(53)$ & 0.09 [2] \\
\hline Bulgaria & BGR & $4.2(41)$ & $3.8(12)$ & $0.41[-29]$ & $1.12(72)$ & $2.47(41)$ & $-1.35[-31]$ \\
\hline Argentina & ARG & $2.24(75)$ & $4.08(1)$ & $-1.84[-74]$ & $1.96(63)$ & $3.78(25)$ & $-1.82[-38]$ \\
\hline Brazil & BRA & $2.91(65)$ & $3.66(56)$ & $-0.75[-9]$ & $2.53(43)$ & $2.08(58)$ & $0.45[15]$ \\
\hline Colombia & COL & $2.69(73)$ & $3.32(71)$ & $-0.64[-2]$ & 2.39 (47) & $2(62)$ & 0.39 [15] \\
\hline Indonesia & IDN & 3.91 (49) & 3.39 (68) & 0.52 [19] & $2.17(55)$ & $2.45(42)$ & $-0.28[-13]$ \\
\hline Peru & PER & $3.99(46)$ & 3.8 (12) & $0.2[-34]$ & $1.94(64)$ & $2.19(54)$ & $-0.25[-10]$ \\
\hline Romania & ROU & $3.76(51)$ & 3.8 (12) & $-0.03[-39]$ & 1.62 (67) & $2.29(47)$ & $-0.67[-20]$ \\
\hline Moldova & MDA & 3.19 (56) & 3.8 (12) & $-0.61[-44]$ & 1.87 (65) & 2.05 (59) & $-0.18[-6]$ \\
\hline Egypt & EGY & 3.32 (55) & 3.8 (12) & $-0.47[-43]$ & $2.01(60)$ & $2.05(60)$ & $-0.04[0]$ \\
\hline South Africa & ZAF & $4.02(43)$ & 3.51 (65) & 0.51 [22] & $0.56(74)$ & $0.79(72)$ & $-0.23[-2]$ \\
\hline Belarus & BLR & 3.17 (57) & $3.8(12)$ & $-0.62[-45]$ & $2.21(54)$ & $2.24(50)$ & $-0.03[-4]$ \\
\hline Algeria & DZA & $2.79(71)$ & 3.8 (12) & $-1.01[-59]$ & 2.03 (59) & $2.16(55)$ & $-0.13[-4]$ \\
\hline Ukraine & UKR & $2.86(67)$ & 3.8 (12) & $-0.93[-55]$ & 0.78 (73) & $2.15(56)$ & $-1.37[-17]$ \\
\hline Senegal & SEN & 3.36 (54) & 3.8 (12) & $-0.44[-42]$ & 1.34 (68) & $1.31(70)$ & 0.03 [2] \\
\hline Syrian Arab Republic (Syria) & SYR & $3.11(59)$ & $3.8(12)$ & $-0.69[-47]$ & $2.27(52)$ & 2.47 (39) & $-0.2[-13]$ \\
\hline Iran, Islamic Republic of & IRN & $2.86(68)$ & $3.8(12)$ & $-0.94[-56]$ & $2.39(46)$ & $2.21(52)$ & $0.18[6]$ \\
\hline India & IND & $3.02(61)$ & $3.93(5)$ & $-0.92[-56]$ & $1.63(66)$ & 1.45 (69) & $0.18[3]$ \\
\hline Kenya & KEN & $2.7(72)$ & $3.8(12)$ & $-1.1[-60]$ & $1.17(70)$ & $1.2(71)$ & $-0.03[1]$ \\
\hline Tanzania, United Republic of & TZA & $2.97(62)$ & $3.8(12)$ & $-0.83[-50]$ & $1.16(71)$ & $0.69(73)$ & $0.48[2]$ \\
\hline Angola & AGO & $2.82(70)$ & $3.8(12)$ & $-0.98[-58]$ & $0.45(76)$ & $0.18(76)$ & $0.26[0]$ \\
\hline Nigeria & NGA & $2.84(69)$ & $3.8(12)$ & $-0.95[-57]$ & $0.48(75)$ & $0.47(75)$ & $0.01[0]$ \\
\hline
\end{tabular}

